\title{
Naturaleza, religión y cultura tradicional: Un ensayo sobre el pensamiento rústico
}

DE ENTRADA

Los elementos naturales tienen un lugar de privilegio en la religión rural: una afirmación sin contradictores y sin consecuencias. La contigüidad del campesino y la naturaleza parece obvia e indigna, así, de más investigaciones.

En otras ramas de estudio -la antropología en general, la etnografía de pueblos exóticos en particular- la materia natural se ha revelado buena para pensar y para gastar ríos de tinta. Pero el campesino, como sabemos, no es un primitivo: tendemos a verlo, o como lo que queda de un primitivo - un guardián de supervivencias culturales- o como un subalterno, que sigue de buen o mal grado modelos dominantes. No esperamos encontrar una Pensée Rustique, y por eso no la buscamos.

Este trabajo escoge esa alternativa descartada, y busca una organización interna y autónoma en los mitos y rituales referentes a la naturaleza. Ello no exige gran alarde metodológico. Basta delimitar un terreno para el estudio, y explorarlo con morosidad, para percibir mejor la naturaleza de esta "naturaleza" campesina, y que ella nos diga algo más de lo que ahora nos dice. El terreno aquí tratado es la Rioja, especialmente su mitad occidental; una base extrapolada siempre que el tema, como en el caso del toro, así lo exige. Los datos que aquí se ofrecen, aunque numerosos, están lejos de ser exhaustivos: la exhaustividad sería imposible (se trata de un campo abierto a innovaciones) e inadecuada para la claridad de la narración.

Me baso en lo que conseguí saber sobre el tema a lo largo de una investigación personal, entre 1983 y 1985, en observaciones directas y en la lectura de una amplia bibliografía ${ }^{1}$. Me voy a permitir sincronizar informaciones de fechas muy dispares. Más de un milenio nos separa de

1 Debe hacerse mención especial al trabajo de Luis Vicente ELf́As, "El medio físico en la tradición religiosa de la Rioja", Apuntes de Etnografia Riojana 2 (Madrid: Unión Editorial, 1983), pp. 123-145, y a su bibliografía sobre temas de etnografía riojana (en Apuntes de Etnografía Riojana 1). 
alguna de ellas; veremos después si ello nos lleva por fuerza al anacronismo.

La primera parte de este escrito parte del árbol, y la segunda del toro; una tercera trata de las abejas, y supone una especie de síntesis. Junto a ellos, protagonistas, hay otros figurantes de importancia que les ayudan a definir su papel. Otros actores quedarán fuera, e historias quizá diferentes podrían escribirse a partir de ellos.

\section{EL ESPÍRITU DE LA VEGETACIÓN}

\section{LA TEBAidA VERDE}

Nuestra sensibilidad actual para esta "religión de la naturaleza" tiene su antecedente menos remoto en una literatura sugestiva -basada en comparaciones a escala planetaria y algo simple tal vez por ello mismocuyo autor más famoso es J. G. Frazer ${ }^{2}$. Él popularizó nociones vagas y amenas como esos espíritus de la vegetación que pueblan los bosques o que controlan la fertilidad del trigo. No faltan referencias a esos dueños de la floresta en los libros clásicos o en el folclore asturiano o vasco, pero el bosque ocupará un lugar muy limitado en esta exposición. En la Rioja no se han registrado driades ni busgosu ni baxajaun; dudo que una encuesta más exhaustiva descubriera sus rastros. Sí existe el bosque como lugar peligroso, como opuesto al poblado, pero también por éso lugar sagrado, elegido para los grandes santuarios:

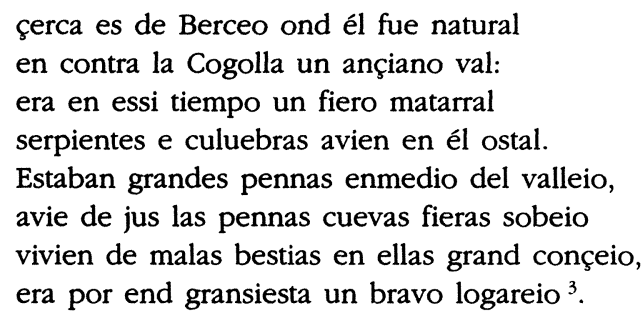

aquel lugar, preservado por el señor para incremento del culto divino y situado en las más profundas simas de grandes montañas, era inhabitable desde antiguo; y, debido a la espantosa densidad de montes, árboles y bosques, servía de apro-

2 Mejores referencias pueden encontrarse en Julio CARO BAROJA: "Culto a los árboles y mitos y divinidades arbóreas", Sobre bistoria y etnografía vasca (San Sebastián: Txertoa, 1982).

3 Gonzalo DE BERCEO, Estoria de sennor Sant Millán, cuartetas 27-28. 
piada guarida a una astutísima serpiente, a jabalíes, a osos y a otras muchas fieras que devoraban a hombres y ganado ${ }^{4}$.

Puede observarse que son las fieras, y no los árboles, los verdaderos emblemas de este bosque. En toda la cristiandad occidental el bosque sustituye al desierto de oriente como ámbito del ermitaño. Sto. Domingo de la Calzada es quien mejor ilustra la versión más "europea" del anacoreta: con su hoz milagrosa tala la masa forestal en provecho del crecimiento urbano y agrícola ${ }^{5}$, repitiendo a lo grande, lo que hacen todos los ermitaños de las novelas del ciclo bretón y abriendo lugar para la ciudad que lleva su nombre ${ }^{6}$. Pero lo corriente en el folclore es que bosque y aldea mantengan un cierto equilibrio. San Millán, que en su vida como eremita en la sierra ha desalojado a las sierpes y otros enemigos, al regresar a su pueblo es recriminado como mal vecino por el diablo, que lo había ocupado entre tanto:

$$
\begin{aligned}
& \text { entresti a los montes por a mi guerrear, } \\
& \text { dizies que al poblado nunqua querries tornar. } \\
& \text { en cabo quando eras çerca del passamiento } \\
& \text { de tornar a poblado prísote grant taliento... } \\
& \text { Aun agora quieres fer otro poblamiento, } \\
& \text { bien me ten por babieca si yo te lo consiento }
\end{aligned}
$$

En suma, el bosque se define de modo negativo: es lugar impenetrable para el simple mortal y arduo para el santo, que en él se encuentra con su mortal enemigo y alcanza méritos. El bosque simbólico riojano está mejor definido por su altitud y su despoblación que por su frondosidad. Es "sierra" o "yermo". El verdadero ídolo vegetal es el árbol individual, no un ambiente sino un personaje.

4 Traducción del comienzo de la Historia Latina de Valvanera, en Pérez ALONSO, Historia de la Real Abadía de Nuestra Señora de Valvanera (Oviedo, 1971).

5 Joseph GonzÁlez DE TEXADA, El Abraham de la Rioja, Santo Domingo de la Calzada, 1702.

6 Otra decepción para posibles frazerianos: en una región intensamente agrícola como la Rioja no hay complejos religiosos de importancia ligados a la fertilidad del suelo, aunque haya patronos de los labradores y, claro está, unos y otros santos protejan las cosechas, como protegen vidas y salud. La religiosidad campesina parece dedicar más imaginación a cuestiones más extravagantes y menos contables que el pan cotidiano, desmintiendo algunos lugares comunes. Lo que no impide que en una región vecina, muy por el contrario, la agricultura pueda ser vista como un don involuntario de los espíritus del bosque. Julio Caro Baroja, op. cit., p. 149.

7 Gonzalo DE BERCEO, Estoria de sennor Sant Millán, cuartetas 114-116. 
El roble de S. Vítores de Zorraquín puede servirnos de paradigma:

[de la ermita] sale un Roble muy grande, y coposo, que se conserva todo el año poblado de hojas frescas, contra lo natural [...] especialmente en esta tierra, que por estar tan vezina a la sierra es muy fría [...] De los ramos de este arbol usa la gente, que padece mal que llaman de monte, o ussagre, y en esta forma. Encomiéndase al glorioso Martyr (cuyo Santo cuerpo dista tres leguas de alli), y dan alguna limosna para luz, o hazen dezir una Missa en su Hermita. Después cortan el ramo, y se le aplican, y le tienen en su casa: y conforme este se va secando, se seca también el ussagre, y se quita, y consume del todo ${ }^{8}$.

O, en el mismo sentido, la encina que hasta finales del XVII se veneraba en la ermita de la Magdalena de Anguiano:

Encina, cuyas raras propiedades vieron, y admiraron muchos; hasta de doze años a esta parte, que un viento furioso la arrancó de rayz, syn dejar renuevo alguno. Las ojas de dicha encina eran suaves, muy crecidas y sin espinas, y en todo diversas de las demás. Cargaba siempre de frutos; pero antes de llegar a la perfección, se caía todo, sin quedar vellota alguna. Por devoción de la misma Santa, tomavan ojas, y ramos della los fieles, con los quales sucedieron raros milagros, mediante la intercesión de la Santa .

o la de la Estrella:

[la virgen] fué aparecida en la Encina, cuyo renuevo se conserva hasta hoy [...] Porque aviendola cortado, por ser muy vieja, produjo el tronco la que hoy se mira en medio del camino del humilladero [...] $\mathrm{Y}$ parece claro fué su primer aparecimiento [de la virgen] en dicha Encina, pues en la antiguedad se llamó N. Sra. de la Encina ${ }^{10}$.

El árbol se venera asociado a un santo o a una virgen, pero no depende de esa advocación; el culto del árbol sobrevive al cambio de nombre, como en La Estrella, o por el contrario desaparece aunque el santo siga vigente, como en Anguiano. El árbol sagrado puede ser un ejemplar anómalo, o perfectamente común; pienso que las anomalías fueron notadas por tratarse de un árbol sagrado, y no al contrario. Del mismo modo,

8 Mateo DE ANGUIANO, Compendio bistorial de la provincia de la Rioja, de sus santos, y milagrosos santuarios (Madrid, 1704), pp. 564-565.

9 Mateo DE ANGuiano, op. cit., p. 643.

10 Mateo DE ANGuiano, op. cit., p. 548. 
el árbol sagrado no es por fuerza centenario: más vale decir que a veces llega a centenario por ser sagrado. El vínculo de la aparición no es imprescindible. El árbol puede compartir el recinto sagrado con figuras del panteón católico sin una relación expresa con ellas. Así, en Soto de Cameros, dos olmos que han crecido espontaneamente en el borde del aterrazamiento de la Ermita de la Virgen del Cortijo son objeto de alguna devoción. Se tomaban, y toman aún, sus hojas para curar dolores de cabeza; cuando un sacerdote tomó un hacha para cortarlos en cierta ocasión, le advirtieron que no lo intentase, "porque el hacha rebotaría y le daría a él..

La función simbólica del árbol no se limita a estos marcos propiamente sagrados, extendiéndose a dominios que convendría llamar más "civiles" que "profanos":

En la región los árboles han sido elementos importantes y respetados. En las plazas, el olmo da sombra y es lugar de reunión como en el caso del término «Encina Conceiera" de Pazuengos. A lo largo de las sierras riojanas hay árboles singulares que durante siglos han sido respetados como el roble de las Palomas de Pradillo, el pino de Sancho Viejo de Villoslada, etc. ${ }^{11}$

No existe en la Rioja esa fuerte tradición jurídica asociada a los árboles del País Vasco ${ }^{12}$, sin que haya que descartarla en un ámbito local en tiempos pasados. Aún es fácil observar su papel como lugar de reunión -no son raras las plazas de pueblos centradas por un árbol. Como símbolo comunitario, puede llegar a definiciones casi totémicas, como en el caso del tejo heráldico del solar de Tejada, que hoy todavía los miembros del linaje, en la medida de lo posible, plantan ante sus casas (un buen ejemplar es el del jardín del marqués de Legarda, en Ábalos).

Aunque nos hemos referido a árboles individuales, en por lo menos dos casos existen grupos de árboles con sentido ritual. Por un lado, tenemos la llamada "Mesa del Santo" de Santo Domingo de la Calzada, hoy una ermita convencional, pero que aún a principios del siglo xvir era un círculo de encinas:

un sitio, que hoy le señalan al final de la dehesa de nuestra ciudad, camino de Castañares, que se llama todavía Mesa de el Santo, entre unas encinas, cuya rara disposición manifiesta bien, que aun la naturaleza las compuso para este efecto: Pues son seis árboles, que componiendo un sitio redondo de doce pies de largo,

11 L. V. ELías, "El medio físico en la tradición religiosa de la Rioja", op. cit., p. 127.

12 Julio CARO BAROJA, "Sobre el árbol de Guernica y otros árboles con significado jurídico y político", Sobre bistoria y etnografía vasca (San Sebastián: Txertoa), 1982. 
y otros tantos de ancho en óvalo, distan en el círculo uno de otro tres pies, con igualdad maravillosa, y con sus ramas hacen dosel a todo el dicho sitio, como vistosa mesa el verde prado ${ }^{13}$.

Nada más lejano que ésto de un hipotético «bosque sagradon: la mesa del santo es lugar de romería, como para el santo fue lugar de caridad para con los peregrinos, pero es precisamente el claro entre los árboles el que centra la atención, recordando el claro abierto por el santo cuando la región era un extenso bosque y no una llanura abierta como ahora. La particularidad del lugar es su carácter de naturaleza maravillosamente uurbanizadan; las encinas en sí carecen de valor conmemorativo o curativo.

Muy diverso es el otro caso de colectividad de árboles, el de los "roblecillos" de Badarán. Desde hacía mucho — - estaba ya antes, ya con mis antepasados, tendrá 300, 400 años...”, según mi informante- se levantaba, en el camino de este pueblo a su vecino, Cárdenas, un roble al que los cuidados de la comunidad dieron un extraño aspecto, mixto de árbol y albañilería, con una Virgen de Valvanera en su interior hueco. Esta disposición servía para recordar la aparición milagrosa de la patrona del pueblo, y valía por una delegación del santuario: había quien rezaba ante él, y quien prendía al tronco ofrendas de flores. Hace muy poco tiempo fue destruido por la árida perversidad de nuestros ingenieros de caminos, para ensanchar la carretera. Fue iniciativa de Juan Marcos, mi informante, hace como quince años, la creación de todo un circuito de réplicas de ese roble: la imagen fue instalada en el interior de otros cinco robles, en los alrededores del pueblo. En septiembre, y como preparación de una de las romerías importantes del santuario -antes del día 8se celebra una fiesta de nuevo cuño en la que los lugareños recorren, a pie y en remolques enramados, el amplio círculo de robles, orando ante cada uno de ellos. El circuito de robles vuelve a poner el pueblo dentro de la circunferencia santa que en tiempos formaron sus muchas ermitas - sin que coincidan sus localizaciones. Como en el caso anterior, el grupo de árboles no equivale al bosque ni al árbol individual, ofreciendo una especie de compromiso entre los sentidos de ambos.

Unas notas, antes de continuar. Los ejemplos aparecidos hasta ahora dan una idea general del "culto del árbol" en la zona. Teorías explicativas apresuradas no van muy lejos: el árbol sagrado puede ser viejo o nuevo, ordinario o extraordinario, vivo o muerto, con santo o contra él. La conjunción de datos históricos y contemporáneos no parece generar disonancias, probablemente porque ese culto ha cambiado muy poco en siglos, y como se ve se actualiza con facilidad. En algunos casos se

13 GonZález TeXadA, op. cit., p. 47. 
mantienen hoy culto y árbol, y en otros con el árbol ha desaparecido el culto. En el caso de Valvanera —que ha servido de inspiración a los árboles reales de Badarán y que es una estampa sumamente conocida incluso para las feligresías urbanas- nos encontramos con algo que no sorprende al devoto, pero sí debe sorprender al investigador: el culto del árbol perdura, pero no el árbol en sí; la existencia declarada del santuario data de su destrucción, a juzgar por los mitos de origen que después relataremos. El árbol como marco o pedestal de apariciones marianas suele constituir el tema central de estudios semejantes a éste (por ejemplo, el ya citado de Elías). El modelo se popularizó mucho - la misma iglesia se lo apropió- y aún hoy perdura en apariciones como las de El Escorial. Pero al igual que en Valvanera, el árbol real falta en muchos otros santuarios - por ejemplo, Carrasquedo, Ayago, etc.- y ello me hace suponer que el "árbol de las apariciones" es un tipo muy específico de árbol sagrado. Trataré de él en un capítulo posterior.

\section{VARIANTES DEL ÁRBOL}

Afirmé en principio que el árbol es un personaje, y voy matizando: personaje, no personificación. El árbol no es un resumen de la naturaleza, objeto de un culto fisiolátrico, sino una pieza de un sistema simbólico que se puede formular a niveles bastante abstractos, y que nos dice más de la sociedad que de otra cosa. Se entenderá mejor atendiendo a las tranformaciones de este símbolo. Hasta el momento se han tratado dos aspectos del árbol:

a) el bosque, sede de seres malignos, definido negativamente como ambiente opuesto a la aldea. Su eventual tala puede ser una acción santificadora y civilizadora.

b) el árbol sagrado, individual,sito en lugar despejado, sagrado o civil.

Con una posibilidad intermediaria, la de los grupos de árboles que delimitan un espacio cultural o sagrado.

Pues bien, hay una operación enormemente común en el folclore europeo, y por supuesto en el riojano, que consiste en la transición periódica, en fechas señaladas, de la situación a) a la b). Es la corta y erección del mayo:

La víspera, el 30 de Abril, a eso de las dos de la madrugada, los mozos iban a cortar el chopo más alto y más grande de los contornos. Lo traían arrastrando o al hombro, y el día 1 aparecía tieso, clavado en el centro de la plaza, desnudo y descortezado. Y así permanecía durante todo el mes. En lo más alto del chopo, en la picota, se ponía dinero para que los mozos trepando con dificultades trata- 
ran de cogerlo [...] Terminado el mes, y desclavado el árbol, si aparecía el dueño se lo llevaba, y si no aparecía lo vendían y lo obtenido se lo gastaban en vino ${ }^{14}$.

El mayo es un elemento habitual en las fiestas de primavera. Tanto en las del mes de su nombre como en las de S. Juan y muchas otras. Vano sería insistir en un tema que ha recibido tratamientos tan extensos y eruditos como el de Caro Baroja ${ }^{15}$. Dentro de los límites riojanos sería también inútil un repertorio de los pueblos que levantan $\multimap$ levantaban no hace mucho- mayos. De un mayo a otro, con todo, hay algo que raramente muda: está privado de ramas (o incluso de corteza) y sirve para marcar un centro de actividades ritualizadas. Por lo demás, las variaciones son infinitas. Puede colocarse en el pueblo, en la misma plaza, o fuera de él, en un enclave sacralizado; pueden ser dos los mayos, como en las fiestas de Viloria de Rioja ${ }^{16}$; en ocasiones se debe trepar hasta su punta en busca de un premio (supra) o para decir algo importante, como en el caso de la romería de San Millán:

poco después los mozos solteros cortan un árbol (encina o roble), y, luego de pulimentarle bien la base, lo traen delante de la enramada del Municipio, lo colocan tieso, y sosteniéndolo vertical entre diez o doce robustos jóvenes, sube a las ramas un vecino casado, de los más ancianos, y pronuncia un sermón Moral: y luego otro, que dice un discurso histórico, teniendo al derredor a todos los Romeros, sentados en la verde alfombra del monte ${ }^{17}$.

Un caso notable, por lo sesudo del ritual, y porque lo que en él se yergue no es ya un mayo, sino un árbol entero.

La cruz tiene una larga historia como transformación del árbol: véanse sobre todo ${ }^{18}$ las leyendas sobre la talla de la cruz de Cristo a partir del árbol del paraíso. Pero esto - y el concepto de axis mundi asociadono tiene mucha relación con la dendrología de la zona estudiada, en la

${ }_{14}$ José CABEZón, Y el árbol perdió sus raíces, folleto publicado por el Ayuntamiento de Anguiano, p. 13.

15 Fundamentalmente, en La estación de amor (Madrid: Taurus, 1983).

16 Bárbara AITKEn, "Las fiestas de Viloria, pueblo natal de Santo Domingo", RDTP, IX (1953), pp. 499-503. Tirso de Molina, en la comedia La Peña de Francia (apud Julio CARO BAROJA, Las Formas Complejas de la vida religiosa, p. 360) ofrece un pequeño tratado de la corta y erección del mayo, explicando entre otras cosas que no puede ponerse más de uno en cada aldea, prueba de lo fino que se hila, y se deshila, en esas cuestiones.

17 Constantino GARRÁN, San Millán de la Cogolla y sus dos insignes monasterios (Logroño: Imprenta Ochoa, 1929), pp. 182-183.

18 Mircea ELIADE, El mito del eterno retorno. 
que el mismo Cristo no juega un papel importante. Cabe reseñar la mención de que con el roble de Valvanera se habría tallado un Cristo ${ }^{19}$ que ni existe ya ni parece haber tenido nunca mucha importancia.

No ocurre lo mismo con un crucificado local, San Vítores, que es clavado al madero durante tres días por los sarracenos: en todo ese tiempo, él les predica sin pausa y sin piedad, hasta que deciden degollarle. San Vítores en la cruz nos recuerda la actitud del predicador aldeano de S. Millán: su cruz, más que un axis mundi, es un centro de prado de romeros.

El carácter de "espíritu de la vegetación" de San Vítores está más claro en otros episodios: su martirio (ver más adelante) le ligará definitivamente a unos árboles, y su cayado le sirve como arma en su lucha con los moros y la Serpiente. San Millán, mientras está encerrado en su cueva cuaresmal, usa también el cayado —blagon, en Berceo- como una prolongación suya: una baldada se cura, tocándolo, cuando el santo lo exhibe por un ventanuco.

El báculo de un santo cercano, Sto. Domingo de Silos, ayuda a las parturientas que lo tocan a llegar a buen puerto aunque su disfrute quedó limitado hace ya muchos siglos a las preñadas de la realeza, y los metales preciosos han disimulado la cualidad avegetal" del atributo. El báculo, en suma, puede sustituir al santo, y constituye otra variante del árbol. No estamos instituyendo una equivalencia "desde fuera". La representación del santo con báculo puede llegar a ser una convención, relacionada con la edad avanzada, o el carácter "pastoral" que la interpretación eclesiástica suscita. Pero habitualmente es ilustrativa: está justificada por algún milagro. Quienes portan el báculo y hacen milagros con él son santos - difícilmente santas, por cierto- que, para hablar en figuras, forman un "partido del árbol" en que el árbol y sus derivados son simbólicamente relevantes y fuente positiva de poder. Sto. Domingo de la Calzada, que es de un "partido" diferente, tiene una hoz, y no un báculo, como instrumento milagroso.

Cierta representación de un artista popular en el atrio de una ermita en Soto de Cameros - ante la que se elevan los dos olmos ya citadosnos da una síntesis: se trata de un bárbaro San Cristóbal que atraviesa un río blandiendo un árbol apoyado en la orilla recordando al cíclope de Góngora, "a quien el pino más valiente/ bastón, le obedecía tan ligero...”. Según la Leyenda Dorada, S. Cristóbal predicó en la India y, teniendo escaso éxito, plantó en tierra su cayado que al instante se convirtió en árbol frondoso. Vale la pena observar que falta en el relieve el único elemento -el Niño Jesús- que cristianiza al gigante. Entre todas las po-

19 PÉREZ ALONSO, op. cit. 
sibilidades icónicas, ésa es la que la devoción popular ha elegido: báculo, árbol y mayo reunidos.

Otra variante del árbol sagrado es la viga. Las vigas usadas en las construcciones de un santuario son objeto o sujeto muy frecuente de milagros. Sus astillas son disputadas, como materia curativa, por los romeros, como en el viejo santuario de Santiago de Jubera ${ }^{20}$, o en San Millán; las vigas se instalan solas, o modifican su forma o su tamaño para ayudar en la construcción. El "milagro de la viga" permite comparar el proceder de santos con atributos divergentes. San Millán se encuentra con que la viga para un silo que construye es demasiado corta: hombre "del árbol", consigue que la viga seca se alargue milagrosamente, aún más de lo necesario ${ }^{21}$. Sto. Domingo de la Calzada, santo deforestador, se encuentra a falta de vigas para su iglesia: las consigue mediante su astucia y con la ayuda de la hoz milagrosa, cortando de un tajo los gruesos robles de sus vecinos. Un relato equivalente sirve a conjuntos simbólicos diferentes, poniendo el acento en elementos diferentes.

En el uso del árbol (particularmente del roble) en la construcción, las condiciones técnicas son también condiciones simbólicas: madera dura y que nunca se pudre, sustenta la casa y le garantiza longevidad. Así, la transformación trivial del árbol en viga, que todos los aldeanos efectúan en la construcción de sus casas, manifiesta el mismo poder y la misma dualidad del milagro por el que la viga ya seca recupera milagrosamente la pujanza del árbol vivo. En el árbol se conjugan de un modo imposible para cualquier otro ser la vida y la inmovilidad, y ésto le da buenas cartas para ilustrar a la perfección algunas vanas ilusiones de la sociedad.

\section{ANDARSE POR LAS RAMAS}

Todas las variantes del árbol anotadas hasta el momento afectan al núcleo del árbol. Pero si tomamos nuestros primeros datos sobre árboles sagrados veremos que se habla de la utilización, con fines sobre todo curativos de hojas, ramas, frutos y cortezas. Junto al uso "nuclear" del árbol hay un uso "periférico" que constituye su inverso, y que encontramos en diversos contextos. En la romería de S. Millán, frente al mayo de la pre-

20 Cf. Juan Manuel DE Heredia TeXADA, Memorial del origen del antiquíssimo santuario del glorioso apóstol Santiago en... la Villa de Jubera, para el siglo xvII.

${ }^{21}$ Veremos más adelante el caso opuesto: técnicas, reales o imaginarias, que se suponen usadas para que un árbol vivo, utilizado como pilar de una casa, no crezca como sería natural. 
dicación, se levantaba una enramada para cobijar al ayuntamiento. El uso de las enramadas ${ }^{22}$ es frecuente, sea en cortejos de la noche de San Juan, como en Uruñuela, Huércanos y el valle del $\mathrm{Oja}^{23}$, sea en ocasiones cívicas, como los arcos que se levantan en las fiestas municipales de Logroño, Sto. Domingo y otros lugares. Dentro del complejo festivo de Sto. Domingo actúa un carro enramado tirado por bueyes: sus ramos de encina adornan la tumba del santo rememorando el primer sepulcro rústico que éste tuvo. El ramo es quizá la forma más habitual de ofrenda: de acebo, como en el milagro de Valvanera, o en la procesión votiva de las doncellas de Sorzano; de laurel, como en el caso de los del Domingo de Ramos, muy adornados hasta no hace mucho, al igual que las citadas aruecas" de Sorzano. En la varias veces citada romería de S. Millán, los niños confeccionaban cruces de avellano y coronas de cantueso con las que retornaban a casa.

Como en el caso de los mayos, sería necesaria una encuesta meticulosa y una exposición extensa para dar noticia de todos estos usos: los ejemplos enunciados dan, al menos, las principales modalidades. La diferenciación de centro y periferia del árbol puede ser reveladora en tanto se corresponde con ciertas oposiciones simbólicas y sociales presentes en el mundo rural. Una, la que separa al mayo, nuclear, tomado como botín, del ramo periférico tenido por ofrenda; el uno se trae, el otro se lleva, y los agentes son por lo común diferentes: los hombres adultos, y principalmente los jóvenes, en el primer caso; mujeres y niños en el segundo. Frente a la romería a pie o en caballerías, muy a menudo para hombres solos, la romería con carros enramados señala la participación de toda la familia. El mayo sustenta una exhibición de fuerza, agilidad e incluso sabiduría; el ramo tiene valencias curativas, necesarias para las edades peligrosas o los momentos de enfermedad. En otra. el mayo se opone a la enramada: mientras el primero sirve de púlpito a un especialista ritual, la segunda cobija a la autoridad civil. Más a menudo falta uno de los dos: así, durante las fiestas, las poblaciones levantan o un mayo que sirve de centro o un arco enramado que sirve como umbral, puerta de acogida. La distancia entre una opción y otra es también la que hay entre un mundo propiamente rural y poblaciones de definición urbana.

Lo confirma una aparente excepción, la de esos ramos que señalan la tumba de Sto. Domingo. Pero conociendo los milagros del santo, sabremos que la tumba aparece habitualmente como casa; dentro de ella el

$22 \mathrm{Al}$ igual que en el caso del mayo remito a CARO BAROJA, La estación de amor.

23 Luisa YRAVEDRA y Elena RUBIO, Leyendas y tradiciones de la Rioja (Logroño, 1949), p. 91. 
santo se mueve y hace ruido, y en ocasiones se asoma a una especie de ventana. Los ramos sobre la tumba se acercan de ese modo a los ramos puestos en ventanas y umbrales en la noche de S. Juan. La tumba del santo se asemeja también al dosel vegetal de la Mesa reseñada anteriormente. En ningún momento se encuentra en el folclore del santo deforestador un mayo, un núcleo arbóreo ${ }^{24}$ : precisamente es el patrón de los constructores, que levantan edificios sin necesidad de pilares de madera. Pero no se desdeñan por ello los ramos benéficos, que circundan, que sirven de pared simbólica.

Las extremidades del árbol, en suma, se asocian siempre a lugares o personajes liminares: dolencias, umbrales, mujeres. Iremos viendo que esa lista no es tan heterogénea como podría parecer en principio.

\section{INTERNO Y EXTERNO}

Ya se ha sugerido más arriba la sustitución del santo por su báculo. El que la metonimia "tronco" - en la jerga y en la acepción corrientesirva para designar al hombre y al árbol muestra que la analogía entre el cuerpo de uno y de otro, que algunos mitos sugieren, está también en la lengua común. La amenaza milagrosa contra quien agreda a algunos árboles sagrados - se cortarán o romperán los brazos- indica que el árbol tiene brazos; la relación entre tronco y rama equivale a la que hay entre cuerpo y extremidad. Resisto la tentación de enumerar ejemplos clásicos o contemporáneos del folclore europeo que ilustran la identificación de un hombre, o de todo un pueblo, con un árbol, o la metamorfosis de seres humanos en árboles; esa mitología explícita queda muy lejos del espacio y el tiempo estudiados. Pero por el contrario tenemos a mano algo así como una mitología implícita y lexicalizada, en que esa analogía entre hombre y árbol queda bien legitimada.

Ahora bien, esa analogía es extremamente defectiva, no es, en otras palabras, una alegoría. Nada nos sugiere una "cabeza" en el árbol simbólico, que tampoco tiene pies. En ningun momento, en mitos o rituales de la región, aparece alguna referencia al miembro del árbol que concentra su valor alegórico en la cultura urbana: las raíces. Desde el de Jessé, los árboles de la cultura europea son seres triádicos que figuran la ascensión, la vinculación entre el suelo y el alto, o la descendencia, la heren-

24 Bárbara AITKEN, op. cit., con preocupaciones muy ajenas a las de este estudio, indicaba que el Santo Domingo de Viloria de Rioja - en cuya fiesta se levantan dos mayos - no es de hecho el mismo santo, sino una versión campesina. 
cia: raíces, tronco y ramas. El árbol campesino que estudiamos - no se trata aquí de símbolos «universales» - es por el contrario un árbol binario, cuyo eje más significativo es el que separa centro y periferia. El árbol sagrado crea un centro, y lo hace, por así decir, como un esqueleto a veces interno a veces externo. Si por un lado tenemos el mayo desnudo, en cuyo alrededor se organiza una comunidad en fiesta, en muchos otros casos, como veremos, el árbol tiene una cavidad que cobija un santo, una imagen, o una colmena: algo, en definitiva, muy parecido a un vientre que genera y alberga y se identifica fácilmente con la casa. Anguiano relata la historia del eremita San Félix de Hornillos, y nos cuenta que su habitación hasta la muerte, fué el hueco de un gruesso tronco de un Acebo, árbol ordinario en estos montes" ${ }^{25}$. El árbol desaparecido de Badarán era sorprendentemente parecido a esas chozas fantásticas que cobijan a los santos ermitaños de El Bosco, parientes próximos de nuestro San Félix.

Ya nos hemos referido al valor simbólico de los maderos usados en la construcción, pero ese valor se extiende de algún modo a toda la casa. Si el árbol vale por una casa, la casa vale también por un árbol. Era costumbre en otros tiempos en la sierra de Cameros - como lo es aún hoy en diversas circunstancias en Cantabria o Asturias- celebrar la construcción de una casa con una merienda y colocando una rama de árbol en la parte más alta del tejado ${ }^{26}$. Más notable es un dato procedente de la Rioja Baja:

En Villarroya [...] hemos oído contar que algunas casas están hechas sobre un pilar central de carrasca sin cortar [...] se buscaba un árbol, se cortaban sus ramas y sobre éste se iban adosando in situ los demás elementos. [Hay] diversas teorías en cuanto a limitar el posterior crecimiento del árbol ${ }^{27}$.

La analogía entre árbol y casa es sugerida tanto desde la mitología como desde la arquitectura: es obvio así que la casa de la que estamos hablando no es sólo un artefacto, o un elemento económico, sino también una entidad que produce y sitúa al hombre.

\section{IDENTIDADES}

Por su aptitud para marcar un centro -ritual, doméstico o civil-y por los mismos ecos de la tradición erudita, que prefiere el árbol

\footnotetext{
25 Mateo DE ANGuiano, op. cit., p. 283.

26 Luis Vicente ELÍAS PASTOR y R. MONCOSí DE BORBÓN, Arquitectura popular de la Rioja (Madrid Ministerio de Obras Públicas y Urbanismo, 1978), p. 160.

27 Elías y MONCOSí, op. cit., p. 62.
} 
"genealógico", parece indudable que el árbol debe ser entendido como un signo de identidad. Lo que aparentemente no nos lleva muy lejos: después del "culto de la fertilidad", el "signo de identidad" ha sido el estribillo más popular y más insignificativo de los estudios etnográficos. Pero esa insignificancia procede quizás de una visión demasiado "opaca" de la identidad.

Reconozcamos que la capacidad "identificadora" del árbol no parece grande. Es lógico que a la hora de definir identidades se escojan conjuntos "totémicos", que puedan sostener una red clara y distinta de diferencias. Leones contra águilas, rojos contra azules. Definir identidades por medio de árboles (un roble contra otro roble) o por medio de santas vírgenes patronas (de aspecto e historial muy semejante) es por lo menos paradójico. Pero es esta paradoja la que nos interesa.

En la zona de nuestro estudio los árboles sagrados se complementan o conviven con dos series de rituales: una que coloca a la mujer en posiciones extremas, excluida de la celebración o convertida en su protagonista; otra que consagra la endogamia local con la expulsión, material o simbólica, de pretendientes de otras comunidades ${ }^{28}$. Los rituales de este último tipo podrían ser compatibles con una identidad "opaca", sustantiva, pero su estrecha vinculación con la otra serie - la de presentación o exclusión de mujeres- introduce una transparencia fatal. En manos de las mujeres, siempre un medio posible de alianza con el otro, sólo puede darse una identidad contingente y dialéctica: a través del exorcismo de lo ajeno y de los ritos etnocéntricos se adivina el compromiso ineluctable con los vecinos-enemigos.

Digámoslo de otro modo: en una sociedad articulada por el parentesco, el modo de definir la identidad es una consecuencia del estatuto dado a la afinidad. En el mundo rural riojano ${ }^{29}$ encontramos una endogamia local más postulada que efectivamente observada, y una actitud hostil a los representantes de pueblos vecinos, manifestada por ejemplo en etnónimos denigratorios, o peleas entre jóvenes. Pero una simple lectura

28 Cf. mi artículo "La mujer simbólica. Imágenes y santuarios", L. DíAz ViANA (ed.), Aproximación antropológica a Castilla y León (Barcelona: Anthropos, 1988). Me refiero en el primer caso a romerías o santuarios donde la presencia de mujeres está vetada y a "procesiones de doncellas", que en buena parte están relacionadas con el mito del tributo de las Cien Doncellas; una epopeya del cierre endogámico, que en el registro mítico corresponde a los rituales del segundo tipo, o sea los organizados por "mocerías" masculinas de una determinada población que con métodos más o menos festivos o violentos procuran monopolizar las mozas núbiles.

29 Luis Vicente ELf́AS, "Sistemas de parentesco y consanguinidad en la Rioja", Apuntes de etnografia riojana (Madrid, 1980). 
de las estadísticas indica otra realidad, en la que los lazos de afinidad establecen alrededor de cada pueblo un círculo cognático mucho más amplio. Las identidades comunitarias son afirmaciones paradójicas que ocultan el comercio matrimonial con los otros. Y las ambigüedades de la identidad son por ello una secuela de la división de los sexos, del carácter dual de la reproducción. El papel ritual de la mujer, en tal situación, deriva de su carácter de introductora de la alteridad.

Es aquí donde el árbol define su papel. Lejos de venerarse en el árbol una fuerza de la naturaleza, se busca en él un modelo idealizado de la comunidad, invirtiendo el artificio por el cual la mujer se convierte en factor de la diferencia ${ }^{30}$. El árbol no sostiene la identidad como un signo que caracterice una comunidad frente a otra, sino como un modelo que permite imaginar la coherencia dentro de cada una de ellas. Por qué puede encargarse de esa función es lo que cabe considerar en seguida.

\section{EL SEXO DEL ÁRBOL}

En nuestro inventario de versiones del árbol sagrado -báculos, cruces, mayos, etc. siempre con connotaciones masculinas- no parece difícil identificar una asociación entre árbol erecto y falo. Pero aunque esa interpretación podría ser congruente con algunas de las manifestaciones que nos ocupan, no lo es con el conjunto. El árbol sagrado, cuyo núcleo tiende a ser asociado a la parte masculina de la sociedad, no lo es por ser un elemento macho. Versiones del árbol con connotaciones femeninas - figuras maternas, funciones uterinas del árbol- abundan, y es en estos últimos casos donde alcanza mayor popularidad y una pervivencia que impresiona al investigador ${ }^{31}$.

El árbol tan pronto puede ser roble (masculino) como encina (femenino). Es más, puede ser "chopa" en una región donde lo común es hablar de chopo. El simbolismo del árbol que aquí se expone depende, por así decir, del sexo en abstracto y no de los sexos concretos; se opone no a un otro lado, sino a la dualidad en sí. Si se le identifica muy a menudo con el sector masculino de la población, como hemos ido indicando, no es porque sea en sí un personaje masculino, sino porque, imagen de la continuidad, sirve de tótem a sociedades que tienden a representarse

30 Sobre esa otredad encarnada por la mujer cf. mi escrito ya citado en la nota 28.

31 Es decir que en esa oposición hombre y mujer podrían muy bien cambiar de lugares y que el árbol puede continuar definiendo la identidad y ser femenino siempre que esa feminidad eluda la sexualidad. 
como invariables, donde las mujeres representan una contraidentidad ${ }^{32} ; \mathrm{y}$ donde el caracter sexual - bipolar- de la reproducción es una fuente de problemas intelectuales y sociales.

Un vecino de Alesanco explica, a propósito del árbol sagrado local: "Chopa es el chopo que tiene retoños al pie, que sirve para replantar". En los primeros textos relativos a árboles hemos encontrado ese mismo tema reiterado por positivo y negativo: la encina de la Estrella "es un retoño de la original", la de Anguiano desapareció porque "fue arrancada por un vendaval y no dejó retoño algunon. Es decir: el árbol sagrado tiene una identidad personal y hereditaria; es igual que su retoño y sustituible por él, no por otro árbol semejante, y por ello su continuidad, su capacidad reproductora, es esencial.

Esta fecundidad le da una ventaja sobre el individuo humano, que irremediablemente se reproduce mediante la bipolaridad, y se enfrenta por ello a un azar que amenaza su identidad: el hijo nunca es igual a su padre. Por el contrario, el árbol —con su reproducción aparentemente clónicaes semejante a la sociedad, que a través de un flujo continuo de individuos que siempre cambian, se reproduce a sí misma sin interferencias ni discontinuidades.

A diferencia de los animales y de muchas plantas cultivadas, cuya reproducción sexual el hombre conoce o incluso manipula, el árbol silvestre aparece -al menos aquel árbol elegido como símbolo- nacido de sí mismo, copia exacta de sí mismo, no un hermafrodita sino un ser previo a cualquier división. El árbol por lo tanto es superior al hombre común, es análogo a la expresión ideal del hombre, y por lo tanto cercano al santo o de su misma sangre. Ahí está la razón de esa facilidad con la que el árbol expresa lo que Lévi-Strauss llamaría la aautoctonía del hombre" ${ }^{33}$ : en su capacidad de originarse directamente de la tierra y desarrollarse sin intervención de las combinaciones caprichosas que gobiernan el encuentro de un hombre y una mujer.

Otro mito, que ya anunciamos antes, ayudará a delimitar mejor la cuestión. Cuando, después de otros intentos de acabar con él, los moros cortan de un golpe la cabeza del muy milagroso S. Vitores de Cerezo, de la herida salieron leche y sangre. La sangre mojó unos troncos de moral se-

32 La relación entre lo masculino y lo femenino, en este registro, no sería una relación entre + y -, o entre $\mathbf{A}$ y $\mathbf{B}$, sino entre, por ejemplo, $\mathbf{x}$ y $\mathbf{x}$; entre un ser genérico y un ser específico.

33 En su famoso texto "The Structural Study of Myth", reproducido como capítulo XI de Antropología Estructural. Lévi-Strauss hace a su vez referencia a un texto de Pausanias (VIII, XXIX 4) que propone el vegetal como modelo del hombre: los primeros hombres nacieron del suelo, de simientes incubadas por el sol. 
cos ya hechos leña y al instante los convirtió en frondosos árboles cargados de flor y fruto; según otros, los morales brotaron ex novo de la sangre del santo. Aún hoy existen en Cerezo de Río Tirón los morales del santo, en lugar distante del santuario, aunque no subsista el muro que en el siglo XVII se les hizo para proteger el lugar de la presencia de los animales. Antonio Álvarez, de quien está tomada la historia, era un escritor inspirado y a veces demasiado ingenioso que glosa las semejanzas y diferencias del caso milagroso con "lastimosos recuerdos de amantes locos" ${ }^{34}$ contados por los poetas, y hace también sus versos para celebrarlo:

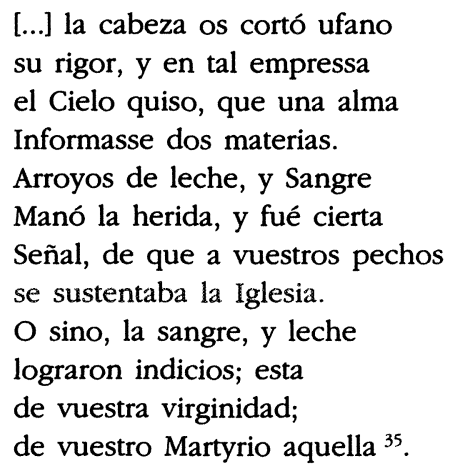

No es una loa ingenua a la castidad sino una exégesis que cala hondo en el sistema que aquí intentamos describir. La vida prodigiosa que la sangre del santo infunde en unos troncos secos es un buen ejemplo de esa perpetuidad ideal que debería asemejar los linajes de árboles y hombres. Pero es un ejemplo límite, porque los morales -dos, si mal no recuerdo-, con sus flores blancas y sus frutos rojos como sangre y leche ${ }^{36}$

34 Se refiere a la muerte de Píramo y Tisbe, narrada por Ovidio en las Metamorfosis, y donde aparecen también unos morales.

35 Antonio Álvarez, Triumpho de la Virtud, dibuxado en la admirable Vida, y peregrina muerte de el Inclyto Martyr de España, San Victores (Madrid, 1694). El episodio ocupa las páginas 80-84, e incluye otros detalles: la leche salpica al verdugo y le hace convertirse al cristianismo. Álvarez comenta y parafrasea textos de S. Ambrosio y del Crisóstomo sobre el martirio de S. Pablo, también con leche. Los morales «de S. Vitores" son aún objeto de culto en las proximidades de Cerezo. Sirven de punto de encuentro para una romería y sus moras, hojas, etc. son buscadas para fines terapeúticos.

36 Las moráceas en general son plantas con látex, lo que puede haber enriquecido la analogía; en cualquier caso, no debemos olvidar que se trata de un árbol milagroso donde, sin ir más lejos, flores y frutos se manifiestan al mismo tiempo; una dualidad más del caso de Cerezo. 
son, en agudo contraste con el roble o la encina, árboles que sugieren sexualidad. Consiguen así recordarnos que la simbología del árbol descrita en las páginas anteriores no depende de significados universales. A partir de los morales de San Vitores podríamos comenzar otra indagación, en que hombre y árboles establecerían relaciones tal vez muy distantes de las que han sido aquí descritas. Pero lo importante es que en ese camino todos los elementos atraviesan por una mutación paralela, como bien entendió el hagiógrafo Álvarez. La virginidad del santo recuerda en cierto modo la autonomía reproductora de la mitología del árbol, pero en un sentido más profundo la niega; aunque prescinda de la relación sexual, la virginidad implica sin duda la sexualidad en sí. Coordinado con un árbol resplandecientemente sexual, el santo se ve a su vez sexualizado o más exactamente bi-sexualizado, capaz al mismo tiempo de fecundar con su sangre y de amamantar, aunque sea simbólicamente, con su leche. Los morales de San Vitores tienen un pie en otro conjunto simbólico bien diferente.

\section{BESTIARIO}

\section{EL TORO COMO "OTRO"}

No es arriesgado inferir que el papel del toro en la mitología campesina sea un negativo más o menos exacto del que cumple el árbol. Ese "ámbito de lo propio" que hemos visto en el primer capítulo simbolizado por el árbol, es el telón sobre el que se destacan las funciones del toro. Si el árbol, gracias a sus cualidades imaginarias, da razón positiva de la comunidad, el toro le proporciona límites.

La mayor parte de los mitos y ritos protagonizados por el toro configuran dos grados diferentes de un mismo esquema. En un caso el toro, que procede de algún tipo de ámbito "salvaje", invade el mundo cultural, cuyos representantes — sean hombres del común o "toreadores" más o menos profesionales- lo detienen, luchan con él y lo expulsan o lo destruyen. En esta categoría entra un sinnúmero de fiestas de sobra conocidas: encierros y corridas que se pueden encontrar en casi cualquier pueblo riojano, versiones modestas de fiestas más famosas próximas en el espacio (pensemos en Pamplona, Soria, Falces, Medinaceli...), o de la tauromaquia "culta" de las grandes plazas.

En una versión "menor", el toro, de nuevo representante de la violencia natural, es reducido a la mansedumbre o incluso a algún tipo de conducta cultural, esta vez por obra no de hombres comunes sino de la 
especial virtud de un santo. El Toro de San Marcos, que tiene sus representantes en la Rioja, ha sido de sobra descrito y estudiado ${ }^{37}$; no muy lejos de él está la vaca de la Virgen de la Vega, en Haro, cuya furia se amansa sólo ante la imagen citada, o los toros amansados por Sto. Domingo de la Calzada, en una variante del milagro atribuido a Santiago en el Codex Calixtinus.

El tema no necesita más glosas de las que ya tiene. En tiempos fue incluso un tópico apetitoso para críticos taurinos modernistas: el hombre y la bestia como instinto y razón, cultura y naturaleza, etc. Para decirlo en términos un poco más abstractos, el toro marca por fuera los límites del mundo humano. Si en el capítulo anterior vimos cómo un árbol vivo era capaz de servir de espina dorsal a una casa, no le falta al toro un papel en ese teatro: la sangre del toro ha sido usada en La Rioja como colorante en la pintura de umbrales y dinteles; un gesto con resonancias bíblicas, y con más resonancias aún en una bibliografía antropológica centrada en nociones como liminaridad y margen ${ }^{38}$.

Esta primera exégesis de la tauromaquia se complementa habitualmente con otra más popular, que trata de los valores de virilidad y fecundidad asociados al toro. La sexualidad del mundo de los toros no es un dato que necesite demostraciones o se preste a ellas, pero parece necesario reconocer su extensión, la ambigüedad que genera a su alrededor, y los niveles en que permite buenas interpretaciones. El tema tiene larga tradición en la antropología española e hispanista, y ha sido objeto de replanteamientos recientes ${ }^{39}$. Pero esos análisis se han centrado generalmente en la tauroma-

37 Sobre el caso riojano, Fernando FERnándEZ DE BOBADIlla, "Supervivencia del culto al toro en Arnedo", Berceo, 56 (1960), pp. 357-362. Sobre el Toro de San Marcos en general, la referencia obvia es el estudio de J. CARO BAROJA publicado en la RDTP, I (1944-5), pp. 88-121 e incluido después en Mitos y ritos equívocos (Madrid: Istmo, 1974).

38 A falta de una justificación teórica más detallada, valga esta cita como reconocimiento de deuda hacia los enfoques "topográficos" de la antropología, cuyo representante más puro puede ser Mary Douglas. Una revisión sistemática de esa literatura se encuentra en Fernando GIOBELlina BRUMANA, Sentido y Orden. Estudios de clasificaciones simbólicas (Madrid: CSIC, 1990).

39 La sexualidad ambigua del toreo fue consagrada en la antropología por Julian PITT-RIVERS, en una serie de artículos: un buen resumen de ellos lo da Manuel DELGADO RuIz, De la muerte de un dios (Barcelona: Ediciones Península, 1986), pp. 106 y ss., que es por su parte el responsable del replanteamiento, al instalar esa sexualidad en una interpretación más general del sistema de parentesco español y sus representaciones. Creo que los datos y los análisis de este artículo - teniendo en cuenta que el objeto y el universo tratado es otro- se armonizan con los de Delgado Ruiz, y los complementan. 
quia profesional. Si los juegos taurinos rústicos se han incorporado en buena medida a la tauromaquia reglamentada, aún restan ámbitos que permanecen ajenos a ella, y que permiten una perspectiva diferente.

Hay un detalle aparentemente ocioso que puede facilitarnos la entrada al tema. En la tauromaquia profesional, que gira en torno de un ejecutor que el ritual hace ambiguo, las normas exigen que el animal sacrificado sea un macho. En las fiestas taurinas rurales, en la hagiografía o el romancero, macho y hembra son protagonistas indistintamente, y falta la figura del torero, con sus elaboradas ambigüedades ${ }^{40}$.

Las vacas pueden sustituir a los toros en muchos festejos populares. Es el tamaño y el talante, más que el sexo del animal, lo que gradúa el peligro del juego: vaquillas, becerros y mansos pueden ser juegos de niños, no así una vaca brava. Vacas y toros protagonizan mitos enteramente iguales: la vaca de la Virgen de la Vega repite el toro de San Marcos.

En función de la primera sección de este artículo, podemos entender el punto central de este argumento. No es el toro solo, sino el par vacatoro quien representa para el hombre una opción simbólica opuesta a la del árbol: frente a la pre-sexualidad de éste, la pareja animal se muestra hipersexualizada. Hay una sobremasculinidad en el toro, una sobrefeminidad en la vaca. Si el árbol, con su linaje utópico, es un modelo hiper-cultural, la pareja de animales sexuados representa la amenaza que para la sociedad supone su propia base natural; esa sexualidad que da cartas al instinto y al azar en la sucesión humana. La interpretación tiene muy poco de arriesgada; se limita a recoger una viejísima condena moral de la sexualidad (parte "animal" del ser humano) acentuando una cierta trama sociológica, que debió contribuir a darle sentido en medios poco inclinados en principio al ascetismo.

Árbol y toro facilitan dos pruebas, respectivamente positiva y negativa, del mismo teorema; esa loa del consanguíneo, esa hostilidad por el afín y ese coqueteo con el incesto que tal vez sean adorno inevitable de toda sociedad cognática.

\section{EL ANIMAL MEDIADOR}

Saliendo por ahora de esos círculos debemos indicar que es aquí, en el contraste con el animal, donde se organiza un mundo genuinamente

40 De hecho, podríamos pensar si las complejidades rituales de la corrida no se derivan en buena medida de la necesidad de condensar en poco espacio un universo vasto. Unidad de escenario, de tiempo y de acción - a fin de cuentas, el toreo "culto" viene del xviII- sustituyen la épica dispersa del toreo rústico. 
natural dentro del mundo simbólico tradicional. Recordemos que el yermo o el bosque de los santos y de los demonios no es un espacio vegetal sino animal, una sombra de la sociedad humana. Pero las relaciones con esa sombra están lejos de ser simples.

El toro no es en realidad sino el miembro más prominente de una extensa fauna mítica que pulula en las hagiografías y en la tradición oral. En ellas encontraremos el toro en papeles ajenos al linaje de la tauromaquia, y similares a los de otros animales menos castizos. Lejos de los ritos agonísticos aunque no tan lejos de los ritos del tipo "toro de San Marcos", encontramos ocasiones en que es la misma bestia la que asume el papel mediador. Así, Anguiano continúa su ya citada descripción de la vida de San Félix, refugiado en el hueco de un acebo:

El sustento correspondió a la habitación, porque se reduxo a las yerbas del campo, crudas, y frutas sylvestres, y a la leche que de limosna le dió largo tiempo una baca cada noche, por disposición de la divina Providencia. Dicha baca se apartaba de las demás de la bacada todas las tardes, y caminando desde la deesa de Sartaguda, iba derecha al Azebo donde el Santo se recogía, y en dándole de mamar se volvía con las demás... Al cabo de largo tiempo advirtió el baquero esta continuación de cada día, y quiso reconocer adónde iba la baca con tal frecuencia, y siempre a el anochecer. Concibió en ello algún gran misterio, y la fué siguiendo, para ver lo que hazía. Llegó la noche y vió cómo en las puntas de las astas se le pusieron dos hermosas luzes, con cuya claridad llegó al Azebo, donde estaba recogido el Santo Obispo: y que en dándole de mamar, se volvió a la bacada. Con esta ocasión [...] se divulgó la fama de su santidad por la comarca. La baca prosiguió sus viajes, como antes, hasta que murió el santo Obispo.

La vida retirada del santo obispo nos ofrece un paradigma muy rico del papel de los animales en la mitología riojana, y en otras narraciones reconoceremos con facilidad sus episodios.

Otros animales silvestres aparecen como guías en el hallazgo de imágenes sagradas, reliquias y santuarios: un gavilán, una perdiz o un jabalí en N. ${ }^{a}$ Sra. la Real de Nájera ${ }^{41}$. Algunos animales domésticos aparecen no ya como descubridores, sino como definidores del lugar sagrado. Es así en el caso del santuario de San Gregorio en Sorlada, donde una mula cargada con el cuerpo del santo habría ido a parar. Otra mula decide también dónde debe reposar el cuerpo de San Prudencio, concretamente

${ }^{41}$ Esa función de animal-guía se prolonga en los milagros secundarios: en uno de los muchos que hace Sto. Domingo de la Calzada, el beneficiario es un devoto libertado del cautiverio de los moros, que se encuentra un león en su fuga. Invoca al santo, y el animal feroz, en lugar de atacarle, le sirve de guía para encontrar el camino de vuelta a su tierra. 
en el Monte Laturce ${ }^{42}$, en un curioso rito adivinatorio, real o legendario; en ambos casos, resulta verdaderamente milagroso que una mula suelta haya escogido lugares tan abruptos. Un buey juega también un papel en el progreso del templo de Sto. Domingo de la Calzada: cuando "revienta" después de tenderse irreverentemente sobre ella, los fieles deciden construir un túmulo de piedra que proteja las reliquias ${ }^{43}$.

A la función de guía que conduce a un lugar sagrado, el animal puede añadir la de guardián de dicho lugar: véase el becerro que según tradiciones locales se encontraría en una cueva en el monte de Entrena, o el toro de la cueva de Vallosceros, en Redecilla del Camino, que guardaría un tesoro, o sería en sí mismo un tesoro, estando hecho de oro. Numerosos mitos de origen de santuarios aprovechan ese motivo. En el santuario de Sta. Casilda, cerca de Briviesca, pero muy frecuentado por los pueblos riojanos, una leona ocupa la cueva en que la santa se debe refugiar y finalmente ser enterrada: la fiera desaloja la cueva cuando la santa lo ordena.

Aparece ahí una paradoja muy extendida en la mitología universal, que ha merecido la atención de autores como Propp o Dumézil: la del oponente "débil" que se convierte fácilmente en auxiliar. Nuestros hagiógrafos más socorridos -Anguiano y González de Tejada - relatan dos versiones sustancialmente diferentes de la vida y martirio de Sta. Coloma. Sin entrar en las relaciones entre una y otra versión, quiero señalar que en ambas aparece una osa. En un caso, la santa sube en dirección a la sierra, decapitada y con la cabeza en la mano, hasta encontrar el lugar donde se debe excavar su túmulo: es una gruta en la que vive una osa feroz, que deja el lugar a instancias de la santa. En la otra versión, la santa es expuesta a la lujuria pública en un lupanar, cuando la fiera baja de la sierra y ataca a un mozo atrevido que había querido aprovechar la situación. Un análisis más circunstanciado, que no cabe aquí, podría mostrar el detallismo con que las dos versiones se reflejan formando un conjunto simétrico en que caben las relaciones entre yermo y poblado, hombre y mujer, animal y humano.

Hay otra función habitual de los animales - muy común en los relatos de la Leyenda Áurea y que cabe entre las de la vaca de San Félixcomo proveedores de alimento de un eremita. En Lomos de Orios, el Santo

42 Mateo DE ANGUiano, op. cit., p. 287.

43 Puede haber sido una ordalía de hecho practicada. Los animales de carga - mulas, sobre todo- sirven para traducir la voluntad divina en muchos otros casos, impidiendo, por ejemplo, que un obispo malhumorado deje sin bendición un hospital que Sto. Domingo de Silos había fundado en su pueblo natal, Cañas. 
Gómez, un eremita al servicio del santuario, tenía encuentros de muy diferentes signos con los animales. En los días de nieve, en que amplias regiones de la sierra quedan hasta hoy mismo aisladas por largos periodos, el Santo Gómez era visitado por dos ciervas, que le daban su leche diariamente ${ }^{44}$. Tal vez con alguna ayuda de una erudición poco rústica, San Formerio de Bañares protagoniza la más pintoresca de estas proezas. En su retiro pastoril lejos de la ciudad pagana:

[...] se solía ocupar de hacer quesos, no de la leche de las ovejas que guardaba,sino de la que le contribuían las fieras sylvestres que poblaban aquellos montes. Acudían a su predicación machos y hembras de varias especies, como son Lobos, Ossos, Tygres, Leones, Ciervos y otras alimañas: y era cosa maravillosa ${ }^{45}$.

Un breve excursus. Como podemos ver, el tratamiento de la fauna en la tradición "popular" no es necesariamente naturalista; el oso, muy presente en los relatos, ha debido subsistir en las sierras hasta fechas relativamente recientes, a juzgar por los topónimos, pero el repertorio no tiene limitaciones ecológicas. Las bestias exóticas entran en el mundo simbólico local por una variedad de caminos. Uno, sin duda, el Camino de Santiago, vehículo privilegiado para las fábulas del ciclo carolingio y posteriormente para la materia de Bretaña. Los hagiógrafos letrados, en el afán de ambientar sus historias de mártires en los coliseos romanos han aumentado también el bestiario rural con fieras exóticas. Pero si no hay limitaciones ecológicas tampoco las hay etológicas. A fin de cuentas, se trata de animales prodigiosos: hay osos mansos y tigresas lecheras; hay también en el romancero - para quien se espante de oírlo llamar "alimaña" - un ciervo feroz, que se alimenta de "manos de hombres" ${ }^{46}$.

La relación entre el hombre y el animal oscila entre la lucha (la devoración, en su caso) y la nutrición recíprocas ${ }^{47}$. Hay aquí por un lado

44 Esas ciervas nodrizas conviven con el otro modelo de animal ya citado. En una ocasión, habiendo ido a otro santuario, el de N. Sra. de la Estrella (ya citado), el Santo Gómez se encontró con que un oso feroz hacía estragos en los alrededores. Fue a buscarlo y lo trajo manso atado con un cordel; el oso repite aquí el episodio del amansamiento de los toros de San Marcos o Sto. Domingo.

45 Mateo DE ANGuiano, op. cit., p. 191.

46 Cf. los romances del "ciervo del pie blanco" citados por Diego Catalán, Por campos del romancero. Estudios sobre la tradición oral moderna (Madrid: Ed. Gredos, 1970).

47 Cabe recordar que en uno de los más clásicos rituales del Toro de San Marcos -descrito en el estudio de Caro Baroja- el toro bebía vino, de manos de un mayordomo de la cofradía. Hubo, claro está, autores que entendieron esa operación como truco; cabe preguntarse si la cultura simbólica de los cofrades era tan estrecha como la de los estudiosos, o si concebían como unidad el valor cultural y el efecto físico del vino. 
una constatación banal: en la predación salvaje o en la cría doméstica, ésas son las relaciones de hecho entre hombre y animal. Lo que esas historias ponen en cuestión, entretanto, son las fronteras entre lo salvaje y lo doméstico, que no corroboran las cotidianas. El toro, del que habíamos partido en nuestro estudio, comparte sus funciones con animales más salvajes y más domésticos que él; e incluso el ciervo puede aparecer dotado de ferocidad. Unos y otros unen el papel de oponente y el de auxiliar. Esa movilidad de los caracteres permitirá introducir contrastes en el mundo cultural, postulando la "bestialidad" de algunos aspectos de la organización social, e identificando modelos sobrehumanos en el mundo animal.

\section{ATRIBUTOS ANIMALES}

En todo el catálogo zoológico, sólo hay un personaje que no admite equívocos: la serpiente. En Valvanera la serpiente aparece en dos versiones bien diferentes, que a veces pueden convivir en el mismo relato. $O$ bien es vecina inmediata de la Virgen, un monstruo que guarda el árbol milagroso, o bien es el habitante (fatalmente expulsado) de una cueva a la que el santo descubridor de la imagen va a pasar sus últimos días. En San Vítores y en Lomos de Orios se habla también de serpientes, en relación de nuevo con vírgenes y con santos. No es difícil saltar de estas serpientes serranas a otros reptiles, más o menos fantásticos y más o menos reptiles, como los dragones, bichas y culebrones del folklore, o al mismo modelo bíblico que surge inevitablemente como un eco de estas historias "paganas". La serpiente junto con el árbol compone una especie de emblema del paraíso, que aparece en algunos edenes locales.

Siguiendo interpretaciones anteriores, podemos establecer sin mucho riesgo que la serpiente es el polo opuesto del árbol en la escala natu$\mathrm{ral}^{48}$; y lo es también del hombre, como homólogo del árbol. Como otras fieras, la serpiente abandona su guarida cuando el santo lo ordena, sin oponer resistencia, pero a diferencia de las otras, nunca llega a transformarse en auxiliar.

Podemos establecer una primera explicación "topológica": si la línea vertical, vía que va de lo humano a lo sobrehumano, es la del árbol - cuya parte subterránea, como hemos visto, es desechada en los mi-

48 Es una tesis que ya formaba parte de la cultura de los bestiarios. En un manual de mitología de 1646 (el Teatro de los dioses de la gentilidad, de Vitoria) se habla de una serpiente, la Chelidra, que vive en las raíces de la encina, y la destruye con su veneno. Ajena a las tradiciones populares riojanas, la fábula encajaría muy bien en ellas. 
tos-, la serpiente se arrastra; es totalmente horizontal y relativamente subterránea, porque habita en escondrijos. La ambigüedad de los demás animales, entre un polo y otro, depende de situaciones intermedias. Como cuadrúpedos están a medio camino entre la vertical y la horizontal: uno de los rasgos capaces de acentuar la función mediadora de los animales es su carácter de bípedos ocasionales, reales o supuestos. Es el caso del oso, el más asiduo elegido como doble animal del hombre, o del león, cuyos representantes más divulgados en tiempos eran los heráldicos, que siempre caminan a dos pies ${ }^{49}$.

Otros atributos contribuyen a organizar el conjunto, aparte de esa "verticalidad». En el caso del toro, es sin duda su carácter simultáneamente doméstico y salvaje. Pero hay otro aspecto más general, que ya fue citado anteriormente, y que abre camino a consideraciones ulteriores: se trata de la leche. La leche, primer alimento del hombre y base de la vida doméstica, en los mitos aparece como el tributo de los animales salvajes al santo eremita: leche de leonas y tigresas, leche de osas, leche de ciervas, leche de una vaca escapada de la vacada. No se trata de un simple alimento, sino sobre todo de un don -véase S. Formerio o el toro de San Marcos- que instaura una comunicación entre los ámbitos de la naturaleza y de la cultura: leche a cambio de palabra sagrada o de vino. En el folclore español, la serpiente es un ser lactante que tiende a robar la leche del ganado y puede ser amamantado por una mujer, pero es incapaz de amamantar por su lado; "predadora" de leche, la modesta serpiente del campo español se gana a pulso su puesto de extraña suprema en el mundo animal ${ }^{50}$.

La leche es un vehículo poderoso y que introduce algunos desasosiegos en el orden social. En el siglo xvir, cuando los estatutos de limpieza de sangre tenían plena vigencia jurídica, médicos y teólogos consideraban

49 Pensemos también en otros mixtos más lúgubres de hombre y animal: macho cabrío, lobo da xente, etc. Los demonios que aparecen en el díptico de San Millán, conservado en el Museo de la Rioja, son una especie de minotauros. Vale la pena notar que esos híbridos siempre son más parecidos a un animal en pie que a un hombre a cuatro patas - una opción simbólica en principio equivalente, pero cargada de connotaciones muy diferentes.

50 En un papel que mitologías de pueblos cazadores, como los amazónicos, reservan a predadores que a su vez no son presas, como serpientes - bien mayores que las ibéricas - y como el jaguar. Vale la pena reparar en que un predador eventualmente peligroso, el lobo (virtual equivalente del jaguar), es preservado en un estado simbólicamente ambiguo por su carácter de mamífero (los mitos sobre niños alimentados por lobos son multitud) y que, en contrapartida, los citados pueblos cazadores desconocen el ordeño y no se interesan por la leche animal; tal vez una razón de la excesiva inquina de los pueblos pastores hacia la serpiente. 
la leche capaz de transmitir caracteres psicológicos o convicciones religiosas, lo que aconsejaba grandes cuidados en la elección de nodrizas. Un ama morisca o judía podría contagiar al lactante una ancestralidad indesea$b^{51}{ }^{51}$. La leche puede anular mediante su influjo horizontal las discriminaciones verticales que separan especies o religiones; es una vía de comunicación peligrosa, porque puede acercar ámbitos que están mejor alejados ${ }^{52}$.

Sangre y leche son las dos sustancias vitales del hombre, pero actúan de diverso modo. La primera, en sentido vertical: destila del árbol genealógico de cada cual, lo conforma y lo define personal y socialmente; la sangre instala. La leche actúa posteriormente. Al contrario de la sangre, procede de una fuente preferentemente femenina y actúa en el sentido de la animalidad, pudiendo así introducir en la definición sanguínea variaciones, "buena leche" o "mala leche" —ésta por desgracia más frecuente, por lo menos en el habla común- ${ }^{53}$.

\section{HOMBRE Y/O ANIMAL}

Si la relación entre el hombre y árbol toma la forma de una analogía distante, el encuentro entre hombre y animal es un cruce metonímico capaz de producir híbridos más o menos completos. No me he ocupado aquí, por ejemplo, de fabulaciones sobre hombres-lobos, que pertenecen a un conjunto de narraciones temática y geográficamente distantes, pero el folclore castellano incluye una narración sumamente extendida - la de Juanito el Oso- que pone en juego elementos afines a los que vamos tratando aquí. Juanito el Oso, en síntesis, es hijo de una mujer que un oso rapta y mantiene en su caverna. Dotado de fuerza extraordinaria, Juanito liberta a su madre, eventualmente matando al oso, y realizando otras hazañas; pero a no tardar él mismo se vuelve indeseable por su fuerza excesiva y por su eventual brutalidad. Los hombres ingenian, como único medio de destruirlo, un gigante de pez en que Juanito se hunde, al atacarlo a golpes.

Resulta interesante, en éste como en muchos otros cuentos populares, la paradójica proximidad a muchas historias piadosas. El control doctrinal

51 Julio CARO BAROJA, Las formas complejas de la vida religiosa (Madrid: Akal, 1978), pp. 508-509.

52 La presencia de sangre y leche en el cuerpo del mártir implica así una castidad magnificada, elevada a autarquía, a desvinculación de toda relación «horizontal".

53 Como en el caso del árbol, no cabe aquí una definición sexual absoluta. La «sangre» se recibe también por el lado materno, y simétricamente el esperma masculino puede ser entendido como un tipo de "leche". Notemos, sin embargo, que el carácter «animal de la leche trasciende esa variación de género. 
de la Iglesia, por muchas fisuras que tuviese, impidió determinados desarrollos de la mitología católica, y forzó así otros, como los relacionados con la virginidad, que aparecerán más tarde. Nada podía impedir, sin embargo, que esas virtualidades narrativas se realizasen en otro ámbito, profano y "vulgar".

La historia de Juan el Oso, por lo demás, ilustra muy bien una tensión esencial en el uso simbólico de la naturaleza: la que hay entre analogía y contacto, entre metáfora y metonimia. Juan el Oso vive su drama entre una mitad y un doble de sí mismo. Todo el conjunto simbólico descrito está entre el árbol —doble, metáfora que puede englobar al hombre- y el animal, metonimia del hombre, que ilustra el poder y el peligro de los encuentros.

Pero los símbolos son muy maleables, y del mismo modo que los morales de San Vítores apuntaban hacia un universo "animal", podemos encontrar también en nuestro bestiario intrigas que conducen a la identificaación del hombre con su "otro" preferido. Sin recurrir a una exploración más morosa, resulta fácil comprobar cómo muchos de los temas tratados hasta aquí se dan cita y se recombinan de un modo inesperado en un conocido romance de toros.

Los mozos de Monleón, como sabemos, acaban pronto su trabajo para ir a correr toros ${ }^{54}$. Uno de ellos va con la maldición de su madre, viuda: así lo traigan en un carro si se atreve a ir. Los mozos van, sin dar ni siquiera respuesta. En el camino, se encuentran con el vaquero, que les da detalles inquietantes sobre el toro que van a lidiar. Además de tener "Ocho años" y ser "muy malo", es un toro huérfano: "la leche que mamó/ se la dí yo por mi manon. Los mozos no hacen caso, aunque no por un exceso de optimismo: "si nos mata que nos mate/ ya venimos sentenciados". El desenlace no podía ser otro: el hijo maldito enfrenta al toro, que lo cornea y arrastra; muere, hablando con sus amigos y metiendo en la herida un pañuelo tras otro. Su cadáver, conforme a la maldición, es dejado sobre un carro a la puerta de la viuda: "aquí tenéis vuestro hijo/ tal como lo habéis mandado".

La versión que sigo concluye con una coda asombrosa:

a éso de los nueve meses/ salió la madre bramando/ los vaqueriles arriba/ los vaqueriles abajo/ preguntando por el toro/ y el toro ya está enterrado.

En la plaza de Monleón se enfrentan, para jugar con las paradojas, un mozo sin padre y un toro sin madre. Los dos deben su carácter a esa

54 Uso la versión cantada por Joaquín Díaz en su recopilación Romances truculentos; es la más larga que conozco. 
carencia: el toro es "muy malo" porque recibió su única leche de manos de un hombre, y el mozo "viene sentenciado" porque su estirpe se reduce a una viuda mezquina. No caben comentarios a los seis versos finales, que confunden con perfección humanos y animales. Esa madre que brama pero también pregunta, esos "nueve meses" que vienen a anunciar un entierro; ese "toro" enterrado y no devorado, de identidad indecisa; toda la trama acaba sugiriendo algo así como un crimen en familia.

El modelo simbólico que hemos definido a lo largo de todo este artículo va, por así decirlo, de una afirmación vegetal - los hombres son idealmente como árboles, coherentes, retoños de un linaje sin equívocos- a una negación animal - los hombres deben mantener a debida distancia su naturaleza animal, su marca salvaje y sexual; sus dualidades, en suma. El romance de los Mozos de Monleón representa otro modelo posible, o más exactamente una inversión del anterior: una genealogía trazada a través de los sexos, de madre a hijo, es algo tan tortuoso como esa nutrición del animal a manos de un hombre ${ }^{55}$. Lo grave del caso es que una y otra cosa - cognatismo y ganadería - son piezas absolutamente corrientes de nuestro modo de vida. Las creaciones poéticas y los ritos hacen aparecer las paradojas que hay debajo de esas trivialidades y recuerdan así que, en un universo simbólico en que la dicotomía sexual es esencial, ese toro criado (para la muerte) por un vaquero puede confundirse con ese hijo concebido y destruido por su madre. La ganadería y la maternidad se acercan no sólo porque las dos ponen en relación naturalezas opuestas, sino porque ambas alternan crianza y sacrificio. Sabemos cuán bien armoniza el mundo de los toros con el culto de la Virgen, y más especialmente con su versión meridional, esa madre sola que llora el hijo sacrificado a sabiendas ${ }^{56}$.

55 Dar de mamar a un animal (algo muy común, por ejemplo, entre pueblos cazadores amazónicos) aparece en nuestra tradición cultural como una violenta inversión del orden (pensemos en la descripción de las Bacantes de Eurípides) o con caracteres propiamente diabólicos (pensemos por ejemplo en los famosos relieves del pórtico de Sangüesa). En este caso se trata de serpientes, que, como vimos, posibilitan una absolutización de la oposición humano-animal. Se cuenta en la Rioja el conocido relato del hombre - un pastor - que alimenta una culebra y es casi devorado por ella cuando la encuentra ya crecida años después.

56 La interpretación de la tauromaquia de DELGADo RuIz, op. cit., pone en juego estos mismos elementos, y los desarrolla con más pormenor sociológico. En un sentido más "culturalista" y generalizador, podríamos aventurar una hipótesis: pueblos ganaderos tenderían a pensar el mundo animal en función de las relaciones de filiación, consanguíneas, reelaborando un universo que los cazadores piensan en términos de mutua devoración y de relaciones entre afines. A pesar de tantas interpretaciones universalistas del símbolo, son muy raros los intentos de comparación entre conjuntos simbólicos concretos. 
Por medio de este entrecruzamiento de relaciones nos encontramos por fin con una identificación plena entre hombre y toro, semejante a la que sugeríamos en la primera sección entre hombre y árbol. No es un hỉbrido como el centauro, no es un ser ambiguo como Juanito el Oso: es un equivalente metafórico. Hay con todo un cambio de signo radical: la analogía entre hombre y árbol equipara seres vivos -0 , como en el caso de San Vítores, seres que reviven-, en Monleón los dos términos de la comparación están muertos. Si alrededor del árbol se arma una ficción de continuidad de la vida, el toro iguala discontinuidades; la que separa los sexos y la que la muerte trae.

Pero la tragedia de Monleón, como la estética de las corridas, es un caso de elaboración extrema de estos elementos. Algunas fiestas "taurinas", más que ese paisaje agonístico, parecen pensadas para ilustrar las dualidades y el tránsito entre sus extremos. Se sabe que en la ermita de San Marcos de Arnedo, después de la misa de la romería del 25 de abril, los vecinos lidiaban en otros tiempos un toro, siendo el cura párroco quien daba los primeros pases, seguido por el alcalde y las demás autoridades. Años más tarde, con la desaparición de las ganaderías próximas a la ciudad, el toro real fue sustituido por una cabeza de toro, conducida por sucesivos portadores, siguiendo también la escala de autoridad: cura párroco, alcalde, etc. Con ese detalle jerárquico o sin él ${ }^{57}$, la antigua e incomún fiesta de San Marcos de Arnedo derivó hacia un tipo de mascarada muy común. Toros o bueyes simulados, y hombres travestidos de mujer, formaban parte del antiguo carnaval de Anguiano, en una función que tiene equivalentes en una fiesta invernal maragata ${ }^{58}$. Pero no hace falta acudir a tradiciones venerables: mascaradas más o menos folklóricas, o parodias espontáneas de la tauromaquia profesional producen con facilidad ese encuentro entre un minotauro ocasional y hombres vestidos de mujer. El travestismo y la transformaciones del hombre en animal son recursos carnavalescos universales, que tienen algunos ejemplos más "rústicos" y más raros en figuras como el artza del carnaval navarro, o, en territorio riojano, los pastores vestidos con cabezas de carnero o cabra del carnaval de Larriba, extinto no hace tanto tiempo ${ }^{59}$.

57 Cf. Fernando Fernández dE Bobadilla, op. cit., pp. 357-358. Ese último detalle, aunque diría mucho en favor del humor del clero y las autoridades de Arnedo, parece un error de interpretación en la lectura del diccionario de Pascual Madoz, fuente esencial de Fdez. Bobadilla.

58 Sobre Anguiano, ver José CABEZÓn, Y el árbol perdió sus raíces. Folleto publicado por el Ayuntamiento de Anguiano. La fiesta maragata es descrita por J. CARO BAROJA, en su clásico El Carnaval (Madrid: Taurus, 1965).

59 Cf. L. V. ELÍAs, "Un Carnaval inédito en la Sierra de Cameros", RDTP, XXXI (1975), pp. 94-99. 
Como se dijo del roble en el primer capítulo, es difícil separar en cuanto al toro condiciones técnicas y simbólicas; o saber en qué medida determinados intereses simbólicos han influido en la relación práctica entre hombre y naturaleza, en la ganadería, en el caso que nos ocupa. No parece arriesgado suponer que el toro llega a convertirse en símbolo privilegiado allá donde la crianza de ganado grande se da en áreas alejadas del núcleo habitado y su cinturón agrícola. Allí, su ambivalencia de animal salvaje y doméstico tiene cabida e interés. Las dehesas ocupan extensos terrenos que separan unos municipios de otros. El toro habita un lugar donde su ferocidad no causa problemas; de hecho, esa misma ferocidad es inducida, en el caso del ganado bravo, por la selección de sementales. El toro no se convierte en símbolo porque sea feroz, sino porque vive lejos, en los límites: su bravura es así deseada, a diferencia de la del carnero o el cabrón, que habitan en el pueblo, aunque sea en pequeños hatos. En el caso del toro, más que representaciones tradicionales sobre la fiera naturaleza nos encontramos con una ferocidad "cultural", decantada por siglos de práctica ritual.

\section{LA BÁRBARA ABEJA}

\section{EL MEJOR FRUTO DEL ÁRBOL}

Muy habitualmente, el árbol aparece asociado con un personaje femenino: la Virgen que, en la Rioja, como ya vimos, tiene por costumbre casi invariable aparecerse en árboles. Habría que examinar si ésto no desmiente una afirmación que adelantábamos al principio, la de que el árbol es símbolo de por sí, y no como residencia o doble de espíritus vegetales. ¿No podrán ser las vírgenes una transformación, una cristianización de esas hamadríades desechadas prematuramente? ${ }^{60}$

Los relatos más populares de la tradición referente a árboles, son los de "invención" de una imagen mariana: sin contar el caso más complejo y célebre, del que hablaremos más adelante -Valvanera - tenemos la Virgen de Redecilla, o la Virgen de Carrasquedo en Grañón, o la vieja advocación de Nuestra Señora del Roble, en Sorzano. Aunque el roble sea el árbol más habitual en estas historias, no faltan otras opciones, como la de numerosas vírgenes aparecidas en un espino; como la Virgen de

60 Cf. en Julio CARO BAROJA, "Culto a los árboles y mitos y divinidades arbóreas", p. 137 , la distinción entre dríadas y hamadríadas y las especulaciones evolutivas respecto a ellas. 
Canalejas, aparecida en un fresno; como la de la Encina ya citada en La Estrella, como la del acebo de la Hermedaña en Sorzano, o como la Virgen del Prado, de Alesanco, encontrada en una "chopa".

Se trata en cualquier caso de árboles comunes en la región, que en general están presentes en otros capítulos de la tradición oral. Las narraciones más detalladas muestran preferencia por árboles grandes, especialmente el roble, cuyos valores simbólicos ya son bien conocidos. Una indagación "etnobotánica" no nos lleva aparentemente muy lejos. Las complejidades pueden buscarse por otro lado, especialmente por las circunstancias que rodean al hallazgo y que se presentan en las narraciones con una riqueza de detalles muy variable.

Valvanera, como veremos, ofrece el caso máximo. Virgen oculta en el roble hallada por un bandido, panales, serpiente, fuente, etc., que se pueden apreciar en el relato resumido más adelante. En el caso de la Virgen de Lomos de Orios, que pertenece a un mundo muy parecido, se dice como en Valvanera que la imagen fue escondida en tiempo de los moros y apareció después en un roble. Le hicieron ermita en la planicie, pero la Virgen volvía milagrosamente al roble. Cortaron entonces el árbol, e hicieron con su madera una peana para la imagen, con lo que ésta aceptó quedarse con sus devotos ${ }^{61}$. La Virgen del Tajo, en Camprovín, ofrece un relato inusual y de gran interés:

un hombre daba con el hacha en el tronco del árbol y oyó una voz de adentro que decía: corta un poco más abajo o me cortarás el brazo. Y entonces se abrió la corteza y dentro estaba la Virgen ${ }^{62}$.

Al margen de casos como ése, versión oral de una tradición que - caso raro en la región - nunca fue puesta por escrito, las ainvenciones de imagen" tienden a estabilizarse en un relato peculiar. El árbol de la aparición, la intervención de pastores, la resistencia de la virgen a ser llevada fuera del lugar y otros elementos forman un conjunto sin duda familiar para el lector, que conocerá versiones más recientes, como las de Fátima o el Escorial. Cabría hacer al respecto algunas consideraciones -especialmente sobre las relaciones entre el yermo y el poblado-, afines a las que inician el anterior capítulo. Pero es preferible trillar aquí un camino algo diferente.

61 Gregorio GonZÁlez PINILlos, Historia de la Milagrosa Imagen de N. Sra. de Lomos de Orios (Logroño: Imprenta El Riojano, 1901). La historia del hallazgo estaría sacada de una información jurídica hecha por el obispado en 1620.

62 Se trata de un relato escrito por un muchacho de Camprovín durante una encuesta sobre tradiciones, en un centro de enseñanza. 
Hay que tener algún cuidado antes de reclutar estos relatos en las filas de algún substrato pre-cristiano que se filtra a través del catolicismo popular. El tema de la aparición de la Virgen en el árbol es de origen obviamente "popular", pero fue adoptado con entusiasmo por la cultura clerical, lo que en buena medida da cuenta de su enorme difusión ${ }^{63}$.

Valvanera, para poner un ejemplo, se difundió por buena parte de España y América como imagen sagrada, y no faltan casos en que esa difusión incluye una reelaboración local del propio mito de origen. Junto al pueblo de Nombredilla, de la comunidad de Daroca, en Zaragoza, había un bosque de olmos, teatro de algunos prodigios: luces misteriosas, árboles que no perdían su verdor en todo el año, etc. Varios vecinos deciden resolver el enigma. Después de ayunar tres días, y descalzos, se internan en el olmedal y descubren en el árbol mayor una virgen tallada en medio relieve en el propio árbol con un niño Jesús que aparta la mirada. Cortan el tronco a su altura, dejando un respaldo a modo de peana. Un devoto peregrino que conoce Valvanera atestigua que es la misma imagen y explica, con el mito contado en Valvanera, el detalle del rostro del Niño; también se asocian las abejas al conjunto, elaborando sus panales en el tronco cortado ${ }^{64}$.

Pero aparte de esos casos, en general geográficamente próximos, el árbol sagrado, a medida que se divulga, tiende a convertirse en una convención: la Virgen tiene que aparecerse sobre algún árbol, arbusto u otra planta, sea rosal, parra, retama, junco, etc. (o cualquier otro que no sea el taller del imaginero) ${ }^{65}$. Hay un continuum desde casos en que el árbol

63 Los relatos de invención de imagen son muchas veces usados como documentos primarios por los estudiosos, pero vale la pena recordar que en esas "leyendas" - con un pie en la voz y otro en el papel- median fuertes convenciones de género. El árbol, el pastor, la "fugan de la imagen sagrada que vuelve al lugar donde fue encontrada, se convierten en tópicos indispensables. Resulta curioso examinar un caso almeriense, descrito por Pedro María y Antonio FERNÁNDEZ ORTEGA, "El santuario del Saliente o la identidad de un pueblon, La Religiosidad Popular (Barcelona: Anthropos, 1989), Tomo III, cap. IX, p. 6: el pobre pastor responsable del hallazgo según la leyenda es un personaje bien documentado, un rico propietario local, por cierto. Las leyendas piadosas con sus pastores y sus bosques llegan a formar en la Edad Moderna una especie de género pastoril "a lo divino".

64 Agustín URCEY PRADO: Historia de Valvanera (Logroño: Imprenta del Comercio, 1932), pp. 432-433.

65 Notemos que al otro lado de esa legitimación de la imagen sagrada por el árbol, hay una deslegitimación también por el árbol. (Cf. los dictados del tipo «yo te conocí ciruelo" que descalifican la imagen supuestamente milagrosa de un santo) y que esa alternativa sigue aparentemente la oposición entre árbol silvestre y árbol doméstico. 
no pasa de adjetivo o apellido del ser sagrado hasta otros en que se impone como protagonista. En los extremos de ese continuum podemos postular versiones "primarias" y "secundarias", más densas y menos densas del relato. Si el status del árbol cambia de unas a otras, cambia también el de la virgen. Podemos comprobar que las versiones "primarias" se ocupan de una talla de la virgen que es encontrada dentro del árbol; y las más recientes, de Fátima a El Escorial, insisten por el contrario en la aparición de la Virgen como personaje activo, que habla, profetiza, aparece y desaparece sobre un árbol perfectamente inerte.

Las relaciones de la Virgen con su árbol son sumamente variables. La pauta de Nombredilla - que en éso sigue a su modelo, Valvanera- es la más habitual: "talaron el árbol" para sacar la imagen. Este hecho se revela significativo si reparamos (véase el caso del Tajo) en que la tala del árbol no es necesaria, ni siquiera adecuada, para la extracción. La actitud del "inventor" de la imagen se acerca más bien a la del buscador de miel silvestre, que simplemente agujerea el árbol hueco. Tenemos por lo tanto que diferenciar un primer episodio - extracción de la imagen- que puede continuarse o no con la corta de éste. Hay vírgenes cuyo culto coexiste con el del árbol, y vírgenes sentadas sobre su tocón. Sería apresurado considerar a las diversas vírgenes como un sólo personaje.

La conexión entre Virgen y árbol merece, por lo demás, una explicación. ¿Porqué se produce allí y no en cualquier otro lugar la aparición? En las versiones "secundarias" el tema lógicamente no se plantea. Las versiones "primarias" pueden incluir una explicación "histórica": fue escondida allí por miedo de los moros, lo que en ese contexto no es más que una remisión a los tiempos primordiales ${ }^{66}$. Hay atisbos de un parentesco menos contingente, como en Nombredilla o en Lomos de Orios, más allá de la mera yuxtaposición que triunfa en la versiones secundarias. ¿Cuál es en definitiva el origen de esa centenaria asociación?

Al parecer no está escrito. Sastrústegui ${ }^{67}$ recoge un cuento vasco que trata del Baxajaun - precisamente uno de esos "genios del bosque" que echábamos de menos al principio, aquí acompañado por su esposa, Basandere- y que bien vale un comentario:

El Señor de los bosques sedujo a una pastora de Baigorri, con quien empezó a tener relaciones amorosas. Celosa Basandere, quiso vengarse de la muchacha y la

66 No faltan intentos de explicación ideados por escritores devotos: en el caso de Valvanera, se habló de que la imagen había sido tallada por San Lucas, y puesta en el tronco por "manos angélicas". Pero esas fabulaciones no han pasado a la tradición oral.

67 José María Satrústegul, Mitos y creencias (San Sebastián: Ed. Txertoa, 1983), p. 136. 
encerró en el interior de un tronco hueco. Taponó luego los dos extremos y la arrojó al río. El agua, que bajaba turbulenta, lo arrastró hasta el puente de San Esteban, donde alguien escuchó los gemidos que salían del interior. Pudieron detenerlo $\mathrm{y}$, cuando abrieron con cuidado, vieron horrorizados el cadáver de la madre junto al niño que acababa de dar a luz [...] el niño fue criado en una buena casa, y más tarde estudió la carrera eclesiástica, llegando a ser obispo de Bayona.

La narración es extremamente sugestiva porque parece ofrecer un paralelo "extracristiano" de las historias de vírgenes encontradas milagrosamente en árboles - un poco como la viuda y el mozo de Monleón ofrecen un reflejo despiadado de la Piedad cristiana. Si la mujer en este caso no es exactamente virgen, su maternidad se debe por lo menos a la intervención de un ser extrahumano; para más señas, un monstruo "vegetal. La mujer, siendo al mismo tiempo continente y contenido, gana su ciudadania en la mitología de los bosques.

Pero bien sabemos que los vascos no son necesariamente nuestros antepasados; considerar sus creencias más "precristianas" que las nuestras es por lo menos una falacia. En lugar de un antecedente, la narración de Satrústegui bien puede ser una consecuencia lateral de las leyendas de vírgenes arbóreas, que abundan también en el País Vasco, empezando por la propia virgen de Begoña ${ }^{68}$. En el caso riojano más rico y antiguo, el de Valvanera, hay detalles que no encajarían en la historia del baxajaun, aunque dan fe de algunas curiosidades equivalentes. Buscar una causalidad histórica, o una temporalidad estricta en cuestiones míticas es una tarea ingrata, porque los mitos parecen tercamente contemporáneos: hamadríades, amantes del baxajaun y vírgenes milagrosas no forman una secuencia histórica, sino un sistema de variantes. Lo que las ilumina no es el pasado, sino el contexto.

\section{VALVANERA}

Vamos a acercarnos con más detalle a una de ellas. El mito de origen del santuario de Valvanera ha sido tratado por mí en otras ocasiones ${ }^{69}$; aludiré aquí muy ligeramente a análisis expuestos en ellas con más calma.

68 Sospecho que un estudio del árbol vasco podría llevar por derroteros muy diferentes a los aquí trazados. En un breviario de mitología vasca, J. M. BARANDiARÁn, Mitología Vasca (San Sebastián: Ed. Txertoa, 1979) da cuenta, por ejemplo, de una versión de Mari, la vieja diosa vasca, como mixto de árbol y ser humano, algo contradictorio con el universo aquí descrito.

69 Aparte de un libro inédito: Los laberintos abiertos: mito e historia en los santuarios riojanos, el tema aparece por extenso en el artículo varias veces citado: «La mujer simbólica. Imágenes y Santuariosn. 
Nuño Oñez, un bandido arrepentido, lleva vida de eremita en la cueva de Trómbalos, junto a Anguiano. Instala en ella un pequeño oratorio de madera dedicado a Sta. Coloma. Vive con su hijo pequeño que un dia, al bajar a por agua por la parede de roca, se despeña y muere. Un varón justo, Domingo, llega a su cueva para compartir el retiro. Cuando Domingo está ausente, Nuño recibe en sueños la visita de un ángel que le ordena dejar la cueva y subir a Valvanera, en busca de un gran roble superior a los demás árboles. Dentro del árbol, explica el ángel, hay varios enjambres de abejas que allí labran sus panales, y sobre ellos una imagen de la Virgen María.

Nuño obedece: sube al monte, y es alcanzado en el camino por Domingo. Juntos llegan al roble que con mucho trabajo derriban. Encuentran los panales de miel de los que se alimentan, y la imagen de la Virgen con su hijo. Talan el roble y con su madera elaboran una imagen de Cristo crucificado. Otro episodio narra la llegada de Coloma - hermana de Nuño- cuya ceguera y posterior muerte el ermitaño interpreta como una prohibición divina de la entrada de mujeres en el santo lugar. Nuño abandona posteriormente el monasterio que se ha construido en el lugar, y sigue valle arriba hasta dar con una cueva ocupada por una serpiente, que le cede el lugar. Por espacio de tres años vive allí el anacoreta alimentado de frutos silvestres. Los habitantes del monasterio, que nada sabían de la morada de Nuño, ven luces prodigiosas en el momento en que él muere, y Domingo llega así a la Cueva del Alambre: sobre sus hombros lleva el cuerpo santo al monasterio. Nuño es enterrado en la misma ermita en que yace su hermana.

Se trata de una narración - la llamada Historia Latina- más o menos tardomedieval, de la que otros hagiógrafos extraen subconjuntos más o menos extensos, más o menos glosados. Añado una versión actual, oral y escueta, recogida en Badarán, del ya citado Juan Marcos:

Pues según la historia, la imagen se apareció a un tal Nuño, que por lo visto era un medio bandolero, que andaba por el monte, como esta gente, estos hombres de rapiña, vaya. Se dedicaban a robar y cosas de ésas, ganao para comer, y éso. $\mathrm{Y}$ es uno de los que se le apareció la Virgen. Tuvo una visión que poco más o menos en el valle que estaba, que sería un roble tremendo de grande, el mayor de todos, y que en el tronco habría una fuente; o sea tuvo esa visión, que habría una fuente y en el roble mismo también un panal, una fuente y un panal, y el hombre se desgañitó por todo el valle, una selva, claro, hasta que se le apareció, y golpeó y estaba dentro.

Conviene añadir que la Cueva del Alambre es un lugar aún reconocido y visitado por algunos devotos. Lo primero que salta a la vista es la notable complejidad del relato, en comparación con la mayoría de los mitos sobre santos, y no digamos vírgenes, de la región. Las historias de santos pueden ser sumamente prolijas, pero siempre por la multiplicación y variación de episodios homólogos sobre un mismo proceso lineal: hay un sólo protagonista. En Valvanera, además de la interferencia de una santa ajena 
-Sta. Coloma - hay toda una familia del santo, atribulada por hechos bastante dramáticos, y una especie de molesto doble del protagonista -el "Santo varón" Domingo- que produce una duplicación del argumento.

Veamos: en la narración, al relato tan extendido de la invención de imagen", se suma un relato típico de vida de santo ermitaño, con la ascensión del bandido Nuño, bosque adentro, hasta el lugar de la serpiente. Los dos relatos, además, no son complementarios sino concurrentes. Una vez hallada la imagen ¿por qué el ermitaño abandona su sede? ¿por qué Domingo, asumiendo un protagonismo del que carecía hasta el momento, lo saca del lugar de su muerte para enterrarlo en otro? Es más, ¿por qué - ya que no es necesario, como vimos- es talado el árbol original? Acerca de la historia familiar de Nuño ya discurrí en el trabajo citado, analizándola en relación con el veto que hasta el S. Xvil se alzó contra la entrada de mujeres en el santuario. La explicación que sigue debe continuar y completar aquélla.

\section{LA MIEL Y LAS CENIZAS}

Es sorprendente la insistencia —en versiones escritas $\mathrm{u}$ orales, en relatos o en glosas- sobre el panal de miel que encierra el roble y del que los ermitaños pueden alimentarse. Del mismo modo sorprende, en la lista de milagros del santuario de Valvanera, la preeminencia que sobre cualquier otro género de manejo curativo adquirió la ingestión o el espolvoreo de cenizas de la cocina conventual. Por milagro que algún falso cronicón atribuye a San Atanasio, la ceniza de Valvanera resultaba siempre extraordinariamente escasa para evitar laboriosas limpiezas a los monjes ${ }^{70}$. La ceniza, como substancia curativa, reemplaza en Valvanera las hojas de la encina de Anguiano o de los olmos de Soto, los frutos de los morales de San Vítores de Cerezo, o los ramos del roble de Zorraquín. No debemos perder de vista que la ceniza en último término, es una transformación del árbol.

Pero vamos a ocuparnos principalmente de la miel. Para Lévi-Strauss, el interés simbólico de la miel está determinado por su calidad de alimento anterior a la cocina; que se consume crudo, sin una transformación cultural, y está no obstante deliciosamente elaborado. La maravilla de Fray Luis de Granada, cuando habla de las abejas, es del mismo cariz: un animal rudimentario, enormemente inferior al oso o al toro, muestra un grado de cultura que el mismo hombre le envidia. No hay en el fol-

\footnotetext{
70 Otro milagro con cenizas conventuales se cuenta en el pueblo de Entrena.
} 
clore nada (fuera de algunas atribuciones medicinales) parecido a una mitología de la miel; no hay — que yo sepa- una Virgen de la Miel. Pero sí hay una Virgen de las Abejas, y hay una mitología de las Abejas, que resulta en buena parte invisible por su propia vigencia.

No es difícil percibir la densa carga cultural que sobrellevan las abejas: en los nombres de sus individuos (reina, obrera, zángano), en el drama que representan (el vuelo nupcial que acaba con la muerte de los zánganos) y en la moralización de sus maravillas etológicas. Incontables veces el mundo de la colmena ha servido para alegorías morales y políticas, tan diferentes como las del citado Fray Luis de Granada, en su Introducción al símbolo de la Fé y Bernard de Mandeville en su Fábula de las abejas. Habría que reservar un volumen extenso, y una búsqueda interminable, para dar una idea cabal de esta materia. Para quien piense que todas esas nociones derivan sin más de las peculiaridades observadas en el animal, bastaría conferir las variaciones del campo semántico de la abeja entre diversas lenguas occidentales, o entre momentos de una misma lengua. El folklore griego arcaico y clásico sobre las abejas las equipara a esposas laboriosas, aunque señalando que la producción de miel exige abstinencia sexual. Nuestra "abeja reina" es una "sacerdotisa" virgen, y Hesíodo no tiene reparos en comparar a Pandora, ese dechado de mujer fatal, con el zángano ${ }^{71}$. A pesar de la proximidad de los temas, esas abejas helénicas traslucen intereses y conocimientos muy diferentes de los nuestros. Fray Luis de Granada, aparentemente más próximo, habla de Rey, Abejas, y Esclavos —una jerarquía con connotaciones mucho más lejanas de las nuestras.

De entre todas estas elucubraciones, la más estratégica es la que se refiere a la reina, y sobre todo al sexo que le corresponde. Es "sacerdotisa", "rey", o "emperador" según la época y el autor; en Inglaterra, los tratadistas llegan a hablar de "rey" o "reina" dependiendo del sexo del monarca reinante ${ }^{72}$, lo que confirma las sospechas de que es el tamaño y la primacía lo que llama la atención, sin más cuidados acerca del sexo y la función de la areinaw. De hecho, los escritores clásicos, que Maeterlinck estaba dispuesto a resumir a Virgilio, nada saben de ese sexo y de esa función. Luys Méndez de Torres en 1586 ya hila fino, y habla de la «maessa o maestra [...] que algunos llaman reyn, y es más expresivo en el enigma que él mismo propone al lector en su tratado de apicultura ${ }^{73}$ :

71 Jean Pierre VERNANT, comunicación personal, en la Universidad de São Paulo, 1993.

72 Cf. Áurea MARTín TORDESILlAS, Las abejas y la miel en la antigüedad clásica (Madrid, 1968).

73 Tratado breve de la cultivación y cura de las colmenas (Alcalá de Henares, 1586). La reimpresión moderna es de la Editorial Amuravi, Torrejón del Rey, 1983. 


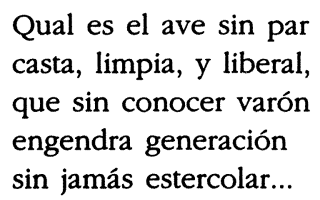

Lo interesante es que se percibe aquí la consagración de un tipo de feminidad soberana y virgen, alejada de la impureza, cuyas posibilidades alegóricas en plena Contrarreforma no escapan a nadie, pero cuya coherencia exigía ignorar el papel generador de los machos, esos zánganos tan denigrados. Vale la pena recordar que en la versión "científica" moderna, la cuestión es algo más compleja: reconocemos que la abeja reina procrea las abejas obreras - que a su vez no procrean- sólo después de su vuelo nupcial con los zánganos; pero sabemos también que la misma reina, aún virgen, es capaz de generar por sí sola esos mismos zánganos, los machos.

Varios siglos antes del epigrama de Méndez, algunos de los más antiguos santuarios marianos de la Rioja ya habían colocado a la Virgen María en una posición de equivalencia topológica con el "panal de abejas" escondido en el árbol, y vale la pena recordar que esa equivalencia permanece actualizada en las versiones orales de hoy, como en el caso de la Virgen del Tajo. Bastaría éso para despertar nuestra curiosidad sobre la apidología "popular" de la actualidad, y aún más sobre su alcance en siglos muy anteriores. ¿En qué se basó la población rural para colocar a la Virgen en el hueco del panal? No fue en las informaciones clásicas procedentes de Aristóteles, Plinio y Columela; aunque por algún milagro estos autores fuesen del conocimiento de los predicadores medievales, de tales autores no se sacarían motivos de peso para identificar la Virgen Madre con el mundo de la colmena. El carácter femenino de la reina se generaliza en la tradición culta europea sólo a partir de naturalistas como Clutius y Swammerdam, a principios del siglo xvII, y la constatación de que la "reina" es capaz de engendrar el macho por partenogénesis la hace Dzierdzon, ya a comienzos del siglo $\mathrm{XIX}^{74}$. Si el conocimiento rural llevaba unos siglos de ventaja al de los autores eruditos, más interesados en grandes alegorías políticas, podríamos entender, en suma, porqué las leyendas populares instalaron las imágenes de la Virgen en el hueco de un árbol. Hubiese o no figuras mitológicas nativas que la precediesen en esa asociación, el nicho lógico y ecológico de las abejas era el único que armonizaba con la figura de una Virgen Madre.

74 La partenogénesis de la abeja, por cierto, es una buena contrapartida simbólica de la costilla de Adán. Los datos sobre historia de la apidología proceden del libro de Maurice MAETERLINCK, Vie des Abeilles, 1901. 
Pero la elaboración de vírgenes y abejas no quedó en éso. Las abejas -en una imagen permitida por la terminología castellana- ilustran un linaje imaginario, donde una reproducción partenogenética en su base perpetúa una comunidad idéntica de cariz femenino, en la que los machos son inútiles al mismo tiempo para la economía y para la identidad de la colmena, siendo así fácilmente eliminados. Lo cual, si repasamos la primera parte de este trabajo, es exactamente una inversión sobre el eje sexual del mundo simbólico organizado en torno de los árboles: una sociedad pura, ilusoriamente masculina, de la que las mujeres son eliminadas ritualmente. Puede así entenderse no sólo la elección del árbol como soporte sagrado, sino también la desaparición del árbol: la virgen es su oponente.

\section{EL ÁRBOL DESTRUIDO}

Efectivamente, recordemos que si el árbol -cualquier elemento vegetal- aparece de algún modo en la práctica devocional de Valvanera, es como árbol consumido, ceniza. La misma aparición de la Virgen es solidaria con esta destrucción: vive, como las abejas, en un árbol hueco. El árbol que cobija una y otras está muerto en alguna medida: hueco, ha perdido o está perdiendo su núcleo. La virgen, de madera, está tallada a expensas del árbol ${ }^{75}$.

Cuando el culto mariano fue introducido en la región - a partir del siglo $\mathrm{XI}$, y especialmente con las reformas religiosas de Alfonso VI- la Virgen debió encontrar su lugar en un catolicismo de santos y santas. Lo mismo ocurrió, más o menos por los mismos siglos, con la figura del Crucificado. Recordemos que, según la Historia Latina de Valvanera, una imagen de Cristo fue tallada en la madera del gran roble: las figuras evangélicas necesitaban establecer alguna relación con el árbol, como ya habían hecho los santos locales (recordemos a Nuño y Coloma) para poder circular en el léxico simbólico local. La Virgen arbórea prosperó a costa de los santos hermanos. El Cristo arbóreo cayó en el olvido, lo que sugiere la complejidad del sistema que tratamos: mientras el Cristo implicaba una transformación simple y directa del árbol, la virgen contradecía, como mujer y como madre de un varón, el trasunto sociológico del árbol. A una sinécdoque se prefirió una paradoja; se subrayaron los aspec-

75 De nuevo podemos aquí percibir la pluralidad latente en un mismo complejo simbólico. Virgilio considera la miel una excreción del árbol, que las abejas se limitan a recoger; está así muy lejos de nuestra fabulación sobre mujeres y miel. 
tos más "escandalosos" de la nueva figura sagrada. En la mayor parte de los santuarios marianos, el Niño es un elemento inerte en la imagen y en el mito. En Valvanera, por el contrario, se hace resaltar su presencia con un mito particular que explica su extraña postura, y que precisamente se refiere a la sexualidad y a la generación ${ }^{76}$. No debe sorprender que esa contradicción mítica entre el árbol sagrado y la virgen madre diese lugar a un ritual contradictorio: el santuario de Valvanera, dedicado a la Virgen y con una feligresía femenina que fue creciendo durante toda la Edad Media, era un lugar prohibido para mujeres. De un modo absoluto hasta el siglo XV, y parcial por tres siglos más, la concurrencia femenina fué objeto de restricciones con sanciones canónicas y sobrenaturales. Ya en el siglo XVII la devoción de Valvanera se había fundido en buena parte con la mariología contrarreformista, que estaba - por su imaginario, por su sentimentalidad y por su ética- muy lejos del esquema simbólico arcaico en el que la prohibición tenía sentido. El culto de Valvanera, extendido ya al sur de la Península y a América, pertenecía más a los forasteros que a los habitantes de las serranías y los valles vecinos: el veto desapareció, como desapareció el árbol y la mitología compleja que envolvía antaño el santuario.

Pero el tiempo anda con pasos diferentes en lugares diferentes. Si la Virgen de Valvanera, para la mayoría de sus devotos, es una advocación más, con algunos epítetos "naturales", los fieles de los pueblos cercanos a Valvanera aún compaginan su culto con el de Nuño. Para ellos, el santuario no es sólo una agencia curativa, sino también un espacio simbólico señoreado por el árbol. Preguntado por el antiguo roble de Valvanera, uno de mis mejores informantes, vecino de Badarán, me dió una respuesta que da punto final a este empeño: "tenemos la creencia porque nuestros antepasados, nuestros bisabuelos lo conocieron todavía. Vigente hace cuatro días, muerto de viejo y no destruido por su sagrada hija, el roble de los mitos sigue siendo allí algo más que un pedestal.

\section{EPÍlOGO, EN VEZ DE CONCLUSIÓN}

El estudio aquí ofrecido no está en rigor necesitado de conclusión. Si las relaciones sugeridas entre elementos diversos del mundo simbólico tradicional parecen verosímiles y relevantes, no hay más que pedirle. Mas cabe recapitular lo pasado desde otros ángulos y buscar consecuencias

76 Sobre el veto a las mujeres en el santuario de Valvanera, y los diversos mitos que lo explicaban, me extendí en el trabajo "Sobre la mujer simbólica" ya citado. 
de lo dicho en otros campos. Con tal objeto, van aquí una serie de consideraciones finales.

Una de ellas se refiere a la naturaleza, que a lo largo de todo el artículo se ha presentado como una materia simbólica que sirve a razones esencialmente sociales. Cabe preguntarse si la naturaleza trasciende de algún modo ese papel; sea ejerciendo una influencia directa en la elaboración simbólica, sea como objeto de una indagación humana que se expresa a través de símbolos pero no se reduce a ellos.

En cuanto a lo primero, debe quedar claro que el universo descrito no es naturalista: aunque ponga en juego obviamente los elementos de la naturaleza local, no se limita a ellos, les trae refuerzos extraños (leones y dragones, sin ir más lejos) y manipula los más cotidianos. Los símbolos no parten de la "vida real", ni traducen intereses económicos cotidianos; si así fuese, tendríamos en la región una mitología de ovejas y carneros. En el final del capítulo "taurino", sin embargo, se sugiere que un encuentro de condiciones ecológicas y económicas pueden conformar guiones diferentes. Las analogías arbóreas y las taurinas constituyen, en ese caso, dos guiones alternativos del mismo enredo, que pueden preponderar según las circunstancias. Es fácil comprobar que la práctica totalidad de los datos referentes a árboles proceden de las zonas de sierra y piedemonte de la Rioja Alta, y que los ejemplos de toros - menos, pero que se podrían ampliar con una multitud de "corridas" rurales - se adensan en la Baja y en las llanuras del valle, donde el paisaje se hace rápidamente "mediterráneo". El papel simbólico del toro desaparece o se modifica en los pueblos de montaña o en la España húmeda, donde el ganado es estabulado en el pueblo (convirtiéndose en algo demasiado doméstico) y donde, por otro lado, el bosque está más cercano, pudiendo suministrar, siquiera a la imaginación, fieras alternativas. Los pequeños poblamientos de la primera son favorables a la metáfora del árbol; los pueblos mayores de la segunda, más apartados entre sí, prefieren la definición negativa que el toro ofrece. Se busca un centro en el primer caso, fronteras en el segundo.

Hay así una cierta razón ecológica en el uso simbólico de la naturaleza. Pero es, por así decirlo, de segundo grado. Ambientes naturales diferentes no generan sistemas simbólicos diferentes, pero dan pie a analogías diferentes entre naturaleza y sociedad: como el pensamiento "Salvaje", ese nuestro pensamiento "rústico" no organiza elementos, sino relaciones.

En cuanto a lo segundo, parece seguro que esas analogías no son unilateralmente "simbólicas". Tienen también sin duda una faz "cognitiva", se basan en un conocimiento local de la naturaleza que en ocasiones -el caso de las vírgenes arbóreas y las abejas tal vez sea un buen ejem- 
plo- puede haberse adelantado no poco al conocimiento letrado. Pero el campo de la etnociencia campesina se encuentra poco cultivado, o poco sistematizado y los estudios sobre simbología no lo pueden utilizar con todo el provecho que sería posible.

Otra consideración se refiere a un equívoco deslizado desde las primeras líneas y que por descuido podría quedar en pie, incluso después de refutado. Es el de hacer de todo lo dicho hasta ahora un capítulo de la religión "rústica", de una mitología propia del campesinado. El presupuesto de esa visión, no poco extendida entre antropólogos, es un paradigma del tipo similia similibus: el campesino tiene una religiosidad "naturalista" con finalidades "agrícolas", es decir, preocupada con la fertilidad, o con adversidades (lluvias, lobos o sequías) que poco conmueven al habitante de la ciudad.

No se puede negar lo obvio: que hay una religiosidad específicamente campesina y que los elementos naturales juegan en ella un papel. Pero se debe reconocer que la dualidad mundo natural/mundo humanizado no corresponde a una dualidad religión campesina versus urbana, porque es una dualidad usada internamente en cada una de esas variantes. Sabemos que el campesinado ha asimilado durante siglos una suma ingente de elementos "eruditos" que desde siempre son por definición urbanos; nuestros análisis apuntan - por ejemplo, para el caso de las vírgenes medievales- no hacia una especie de ósmosis en que esos elementos venidos de fuera se aclimatarían sin ruido, sino hacia una elaboración desencadenada precisamente por la extrañeza de las novedades. Por otro lado, debemos observar la fuerza con que el catolicismo urbano, tal vez en España más que en otros lugares, se ha aferrado a símbolos "rurales". No sólo por la adaptación y difusión de motivos como el del árbol de las apariciones, sino también por la adopción del propio campesino como modelo de autenticidad religiosa, que se dio durante una larga fase de urbanización; esa fe de labriego que no tuvo lugar ni en el primer cristianismo ni lo tiene en la reciente modernización católica, que restituye al campo su viejísimo estatus "pagano".

Otra consideración debe dedicarse a la línea de interpretación usada a lo largo del artículo. Toda la argumentación se ha basado en un código sociológico, y ese sociologismo merecería alguna justificación. Las escuelas modernas de interpretación tienden a poner en juego una pluralidad de códigos, pero esa pluralidad tiene en el caso estudiado algunas importantes restricciones. Parece claro que algunos posibles desarrollos están vedados por la condición subalterna del espacio religioso (campesino o no) que está en foco. Los símbolos de que tratamos no pueden - a no ser en casos muy limitados y marginales- articularse en un conjunto 
cosmológico o cosmogónico, porque en el catolicismo la manipulación de esos niveles está reservada al clero, que no se ha descuidado de ocuparlos; cabe también suponer que el desarrollo de una vinculación entre lo simbólico y lo cognitivo (la etnobotánica, esencialmente) se vea dificultado por esa imposibilidad de un universo simbólico autónomo y completo.

Está claro por otro lado que la sociología y el ritual han resultado mucho menos maleables para las élites evangelizadoras. En cuanto a la sociología, la Iglesia impuso a los paganos una política de extensión y endurecimiento de la prohibición del incesto y una policía de costumbres sobre cuyos resultados habría quizás mucho que decir. Pero pocas posibilidades tenía de imponer modelos sociológicos positivos, entre otras cosas porque antes del éxito barroco de la Sagrada Familia quizá la Iglesia no tuviese ideas sociológicas demasiado claras. Los estudios históricos de parentesco no están entre los ramos más populares de la antropología, y es obvio que en el norte de España el terreno no está suficientemente trillado. Proyectar en el pasado rasgos sociológicos del presente es arriesgado pero no desencaminado, en la medida en que mudan menos que otro tipo de datos, y en la medida en que otros rasgos asociados a ellos (el tipo de poblamiento, por ejemplo) no hayan sufrido cambios radicales. En cuanto al ritual, es de sobra conocida la pugna eterna, y sin un vencedor definido, entre las jerarquías eclesiásticas y la tradición local. Escandalosos, inmodestos, supersticiosos, ingenuos o irracionales, los rituales populares tienen cabida en el canon católico en virtud de un compromiso político que no siempre tiene la misma fuerza: pueden ser ensalzados un día y prohibidos al otro, y sobreviven bien a ambas actitudes. En otras palabras, el cristianismo montó una máquina de controlar el discurso, que fallaba mucho cuando se enfrentaba con algo no perfectamente discursivo ${ }^{77}$; lo indecible resiste mejor.

En fin, y para acabar con estas vueltas, ya que lo que tenemos entre manos es lo que sobra de un discurso imposible, podremos preguntarnos si hay en definitiva algo que podamos llamar "pensamiento rústico" - sea o no campesina esa rusticidad-. Aún más, podemos preguntarnos si después de Wittgenstein la distinción pensamiento/lenguaje es verdaderamente relevante. Creo que lo es si, en lo que respecta al pensamiento, la connotación de "interno" se substituye por algo así como "virtual". Los rústicos devotos de nuestra historia podrían ser así buenos pensadores, aun cuando fueren malos retóricos. Mitos y ritos esbozan relaciones complejas en-

77 Basta percibir en la España actual la homogeneidad religiosa esencial, y la cotidianeidad de la blasfemia, para concluir que la Inquisición, tribunal de doctrina y de costumbres, triunfó en su primera función y fracasó en la segunda. 
tre las piezas que componen el mundo y arman así un mundo peculiar. El universo simbólico que hemos estado describiendo se yuxtapone y se vincula al catolicismo, pero el catolicismo no es su significado. En rigor, no significa nada, pero pone la vida en condiciones de significar algo.

\section{Óscar Calavia Sáez}

Departamento de Antropología, Universidad Federal de Santa Catarina Brasil

Los elementos naturales presentes en el folklore religioso de La Rioja, en el norte de España, árboles, toros y abejas, en primer plano, son analizados en este estudio en sus componentes sociológicos (las ideas que reflejan sobre consanguinidad, alianza e identidad de grupo) y organizados en una sucinta cosmología, que incluye nociones sobre el cuerpo, los géneros y la propia "naturaleza". Se explora la virtualidad de un "pensamiento rústico", diferente del cristianismo pero contemporáneo suyo (no una mera supervivencia del pasado) y el lugar que ocupa en la historia del catolicismo español.

This study focuses on the natural elements in the religious lore of La Rioja, in northern Spain: mainly trees, bulls and bees in myth and ritual. It stressess their sociological and cosmological meanings: patterns of kinship, marriage and group identity, ideas about gender, body and ultimately snature. Furthermore, it this study proposes on implicit arustic mind, contemporary wilto but apart from Christian tought (not a mere survival of the past) and discusses the role of this "mind" in the history of Spanish Catholicism. 